\title{
GEOLOGY AND MINERAL RESOURCES OF
} THE FLORENCE, BEAUFORT, ROCKY MOUNT, AND NORFOLK $1^{\circ} \times 2^{\circ}$ NTMS QUADRANGLES

\section{NATIONAL URANIUM RESOURCE EVALUATION PROGRAM}

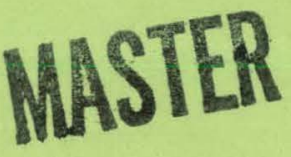

W. BURLEIGH HARRIS

E. I. du Pont de Nemours \& Co. Savannah River Laboratory Aiken, SC 29808 


\section{DISCLAIMER}

This report was prepared as an account of work sponsored by an agency of the United States Government. Neither the United States Government nor any agency Thereof, nor any of their employees, makes any warranty, express or implied, or assumes any legal liability or responsibility for the accuracy, completeness, or usefulness of any information, apparatus, product, or process disclosed, or represents that its use would not infringe privately owned rights. Reference herein to any specific commercial product, process, or service by trade name, trademark, manufacturer, or otherwise does not necessarily constitute or imply its endorsement, recommendation, or favoring by the United States Government or any agency thereof. The views and opinions of authors expressed herein do not necessarily state or reflect those of the United States Government or any agency thereof. 


\section{DISCLAIMER}

Portions of this document may be illegible in electronic image products. Images are produced from the best available original document. 


\section{DISCLAIMER}

This report was prepared by E. I. du Pont de Nemours and Company (Du Pont) for the United States Department of Energy under Contract DE-AC09-76SR00001 and is an account of work performed under that Contract. Neither the United States, the United States Department of Energy nor Du Pont, nor any of their employees, makes any warranty, express or implied, or assumes any legal liability or responsibility for the accuracy, completeness, or usefulness of any information, apparatus, product, or process disclosed herein, or represents that its use will not infringe privately owned rights. Reference herein to any specific commerical product, process, or service by trade name, mark, manufacturer, or otherwise does not necessarily constitute or imply endorsement, recommendation, or favoring of same by Du Pont or by the United States Government or any agency thereof. The views and opinions of authors expressed herein do not necessarily state or reflect those of the United States Government or any agency thereof. 


\section{GEOLOGY AÑD MINERAL RESOURCES OF THE ELORENCE, BEAUFORT, ROCKY MOUNT, AND NORFOLK $1^{\circ} \times 2^{\circ}$ NTMS OUUADRÁNGLES

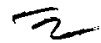

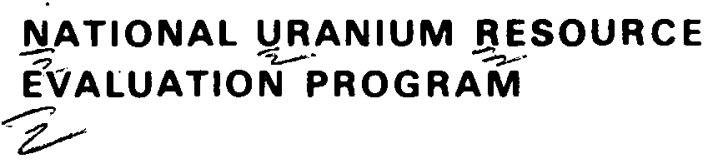

NATIONAL URANIUM RESOURCE ÉVALUATION PROGRAM 2

W. BURLEIGH HARRIS

\section{Approved by}

C. E. Coffey, Research Manager Analytical Development Division

Publication Date: August 1982

\section{E. I. du Pont de Nemours \& Co. Savannah River Laboratory Aiken, SC 29808}

PREPARED FOR THE U. S. DEPARTMENT OF ENERGY UNDER CONTRACT DE-AC09.76SR00001

DISTRIBUTIOA OF THIS DOCUMENT IS UHIBATED

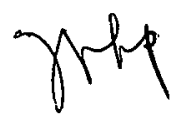


SUMMARY GEOLOGY OF THE

FLORENCE, BEAUFORT, ROCKY MOUNT, AND

NORFOLK $1^{\circ} \times 2^{\circ}$ NTMS QUADRANGLES

BY

W. Burleigh Harris

Department of Earth Sciences

University of North Carolina at Wilmington

Wilmington, NC 


\section{THIS PAGE}

\section{WAS INTENTIONALLY LEFT BLANK}


This document provides geologic and mineral resources data for previously-issued Savannah River Laboratory hydrogeochemical and stream sediment reports of the Beaufort, Florence, Norfolk, and Rocky Mount $1^{\circ}$ $x 2^{\circ}$ National Topographic Map Series quadrangles in the southeastern United States.

This report is issued in draft form, without detailed technical and copy editing. This was done to make the report available to the public before the end of the National Uranium Resource Evaluation program. 


\section{THIS PAGE \\ WAS INTENTIONALLY \\ LEFT BLANK}


Papers

Geology and Mineral Resources of the Florence $1^{\circ} \times 2^{\circ}$ NTMS

Quadrangle, North Carolina, by $\mathrm{W}$. Burleigh Harris . . . .

Geology and Mineral Resources of the Beaufort $1^{\circ} \mathrm{x} \cdot 2^{\circ}$ NTMS

Quadrangle, North Carolina, by $W$. Burleigh Harris . . . .

Geology and Mineral Resources of the Rocky Mount $1^{\circ} \times 2^{\circ}$ NTMS

Quadrangle, North Carolina, by Burleigh Harris

Geology and Mineral Resources of the Norfolk $1^{\circ} \times 2^{\circ}$ NTMS

Quadrangle, North Carolina, by W. Burleigh Harris

LIST OF FIGURES

Figure 1. Sources of data for the generalized geologic map of the Florence quadrangle. . . . . . . . . . . . .

2. Sources of data for the generalized geologic map of the Beaufort quadrangle. . . . . . . . . . .

3. Sources of data for the generalized geologic map of the Rocky Mount quadrangle.

4. Sources of data for the generalized geologic map of the Norfolk quadrangle.

Plate 1: Geologic Map of the Florence $1^{\circ}$ x. $2^{\circ}$

NTMS Quadrangle............... in back

Plate 2: Geologic Map of the Beaufort $1^{\circ} \times 2^{\circ}$ NTMS Quadrangle................. in back

Plate 3: Geologic Map of the Rocky Mount $1^{\circ} \times 2^{\circ}$ NTMS Quadrangle................. in back

Flate 4: Geologic Map of the Nurfolk $1^{\circ} \times 2^{\circ}$ NTMS Quadrangle................ . in back 
THIS PAGE

WAS INTENTIONALLY

LEFT BLANK 


\section{INTRODUCTION}

The National Uranium Resource Evaluation (NURE) was established to evaluate uranium resources in the United States and to identify areas favorable for uranium exploration. The Grand Junction office of the Department of Energy (DOE) was responsible for administering the program. The Savannah River Laboratory (SRL) was responsible for hydrogeochemical and stream sediment reconnaissance (HSSR) of 3.9 million square kilometers ( 1.5 million square miles) in 37 eastern and western states.

This document provides reports on the geology and mineral resources of the Beaufort, Florence, Norfolk, and Rocky Mount $1^{\circ} \times 2^{\circ}$ National Topographic Map Series quadrangles in the southeastern United States. The individual reports were prepared for SRL by Dr. W. Burleigh Harris, University of North Carolina at Wilmington, in 1978 and 1979. There is often duplication of information among the reports.

The purpose of these reports is to provide background geologic and mineral resources information to aid in the interpretation of NURE geochemical reconnaissance data. All reports are accompanied by geologic and mineral locality maps.

NURE hydrogeochemical and stream sediment reconnaissance data for three of these quadrangles have been issued previously. They are listed in the references.

\section{REFERENCES}

SRL-146, SRL-NURE Data Reports, E. I. du Pont de Nemours \& Co., Savannah River Laboratory, Aiken, S.C.

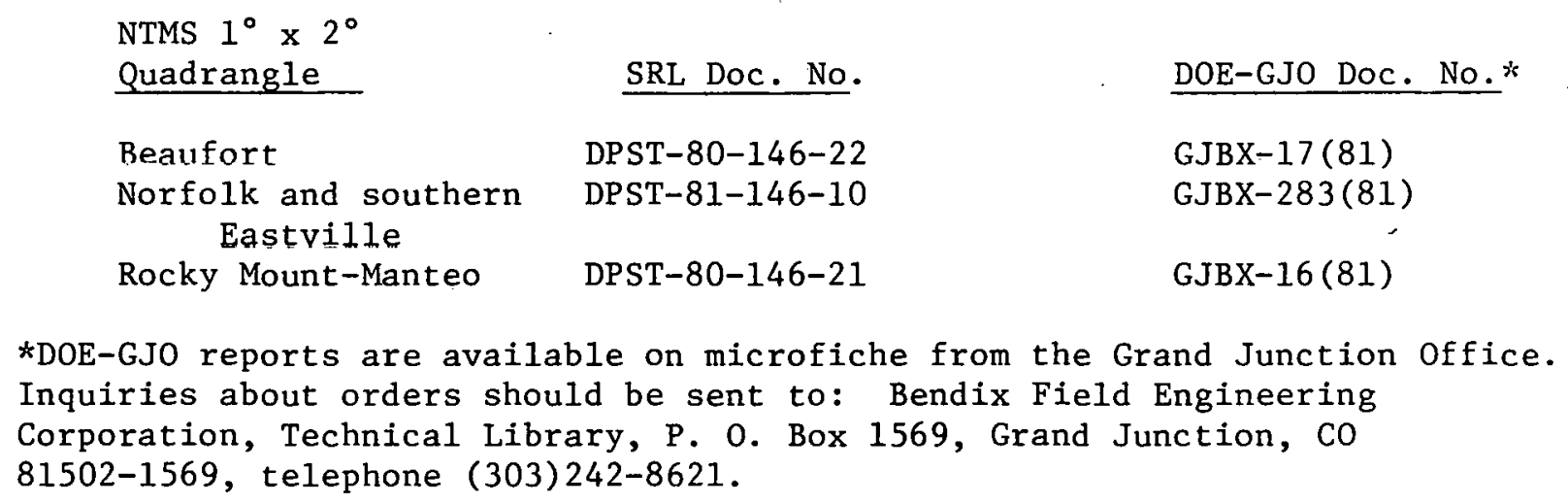

*DOE-GJO reports are available on microfiche from the Grand Junction Office. Inquiries about orders should be sent to: Bendix Field Engineering Corporation, Technical Library, P. 0. Box 1569, Grand Junction, Co 81502-1569, telephone (303) 242-8621. 


\section{THIS PAGE \\ WAS INTENTIONALLY \\ LEFT BLANK}


$\cdot$

GEOLOGY AND MINERAL RESOURCES OF THE

FLORENCE

$1^{\circ} \times 2^{\circ}$ NTMS QUADRANGLE

1 
THIS PAGE

WAS INTENTIONALLY

LEFT BLANK 
Location and Physical Geography 12

Stratigraphy 12

Piedmont 12

Coastal P1ain 13

Structural Geology 19

Mineral Resources 19

- Geologic Literature For The Florence Area 20

Geologic History 21 


\section{LOCATION AND PHYSICAL GEOGRAPHY}

The Florence $1^{\circ} \times 2^{\circ}$ NTMS quadrangle covers about 20,000 square kilometers in North and South Carolina and Includes the Coastal Plain Physiographic Province and a small part of the Piedmont Physiographic Province. Elevations range from about $160 \mathrm{~m}$ in the extreme northwestern part of the quadrangle to about sea level in the eastern part of the quadrangle. Rainfall averages about $108 \mathrm{~cm}$ per year. Temperatures are moderate, averaging about $27{ }^{\circ} \mathrm{C}$ in July and $6.6^{\circ} \mathrm{C}$ in January (Florence). Dense vegetation, the existence of a thin veneer of surficial sand, and a deeply weathered soil profile make geologic mapping difficult.

In the Florence quadrangle, the Atlantic Coastal Plain is physiographically divisible into three distinct parts. The upper Coastal Plain extends from the fall line to the Orangeburg scarp at an approximate elevation of $+75 \mathrm{~m}$. The middle Coastal Plain extends from the Orangeburg scarp $(+75 \mathrm{~m})$ to the Surry scarp at about $+33 \mathrm{~m}$. The lower Coastal Plain extends from the Surry scarp $(+33 \mathrm{~m})$ to the coastal margin. "Geomorphically these three regions are characterized by differing combinations of primary depositional topography (beach ridges, etc.) and subsequent erosion (scarps, etc.)" Colquhoun (1974).

A vast system of creeks and rivers of two major types drains the quadrangle. Heading in the Piedmont, the Cape Fear River and the Pee Dee and Lynches Rivers drain the northern and southern part of the quadrangle, respectively. Heading in the Coastal Plain, the Little Pee Dee - Lumber and Waccamaw Rivers drain the central part of the quadrangle. Interstream areas are gently rolling, with steepest topography usually adjacent to the major drainage systems.

\section{STRATIGRAPHY}

Piedmont

Carolina Slate Belt Rocks

In the extreme northwest part of the quadrangle, Carolina slate Belt rocks occur in stream and river valleys. They consist of a volcanicsedimentary sequence overlying what is often referred to as the Charlotte Belt. The lower part of the Carolina Slate Belt consists of mafic volcanic and sedimentary rocks, including fine- to coarse-grained amphibolite, hornblende schist, hornblende gneiss, actinolite schist, and chlorite schist; some diorite, metagabbro, and biotite gneiss occur. overlying these materials are felsic pyroclastic and volcaniclastic rocks. The uppermost of the Carolina Slate Belt are grey and greenish-gray argillite, slates, and graywacke. Regionally these rocks are in the greenschist facies of metamorphism.

\section{Lilesville Granite}

The Lilesville Granite crops out in the northwest part of the quadrangle and is a sheet- or tongue-shaped concordant mass of compositionally zoned adamellite, granodiorite, and tonalite. It is characterized by a porphyritic rapakivi texture with a medium- to coarse-grained matrix of plagioclase, quartz, and biotite. The pluton, 
which is surrounded by a contact aureole of metasedimentary schist and mica gneiss, contains numerous xenoliths throughout, but they are most abundant near contacts with country rocks. The Lilesville pluton has $\mathrm{Rb}-\mathrm{Sr}$ isochron age of $332 \pm 12 \mathrm{~m} . \mathrm{y}$. (Fullagar, 1974, personal communication).

\section{Triassic Undifferentiated}

Two sma11 parts of the Wadesboro Basin are present in the extreme northwest corner of the quadrangle. The Triassic sedimentary. rocks strike $\mathrm{N} 33^{\circ}$ and dip about $20^{\circ}$ toward the southeast. The sediments consist mainly of sandstone, siltstone, and lesser volumes of conglomerate and clay. The sandstones are arkosic wackes and feldspathic wackes. General1y, arkosic wacke occurs along the eastern margin and the interior of the Wadesboro Basin while feldspathic wacke occurs throughout the basin. Conglomerates and fanglomerates are limited to the structurally splintered western border; they are lacking along the eastern border: These rocks are considered to be of late Triassic to early Jurassic age:

\section{Diabase}

Several northwest-trending Mesozoic diabase dikes occur in the extreme northwest part of the quadrangle. The dikes range in thickness from less than $1 \mathrm{~m}$ to about $340 \mathrm{~m}$, with a median width of about $15 \mathrm{~m}$. Most of the dikes in this swarm are olivine normative and olivine-modal tholeitic diabases. The dikes are considerd to be earliest Jurassic in age ( $P$. A. Thayer, 1978, personal communication).

Coastal Plain

\section{Cape Fear Formation}

The term Cape Fear was originally applied by Stephenson (1907) to exposures on the Cape Fear River below Fayetteville, North Carolina and to those on the Neuse and Tar Rivers and Contentnea Creek. Abandoned from usage by Cooke (1936), the name was re-introduced by Heron (1958) for the casily diotinguished bede in the Cape Fear valley couth of

Fayetteville. Swift and Heron (1969) formally proposed that the name be reaccepted for the basal Cretaceous beds of the Cape Fear River valley. The Cape Fear Formation rests on crystalline basement and is unconformably overlain by the Middendorf or Black Creek formations.

The Cape Fear Formation is a sandstone (quartz to feldspathic wacke) with intercalated layers of mudstone and is estimated to be $15-70 \mathrm{~m}$ thick along the Cape Fear River. The sandstones usualiy have quartz pebbles or intraformational conglomerate at their base and a matrix principally of montmorillontic kaolinite or kaolintic montmorillonite clay.

The most characteristic feature of the Cape Fear Formation is the very thick-bedded stratification expressed as alternating layers of sandstone and mudstone. Most sandstone layers are from 1 to $5 \mathrm{~m}$; mudstone layers seldom exceed $1.5 \mathrm{~m}$. Many sand layers are massive; 
however, cross-bedding may be seen at some localities. Cape Fear strata have characteristics that point to deposition by fluvio-marine turbidity currents in estuaries along an embayed coast (Heron and others, 1968). The Cape Fear Formation is essentially nonfossiliferous, with minor amounts of lignite, twigs and branches, and insect parts (?). A1though Swift and Heron (1969) originally favored a Lower Cretaceous age for the Cape Fear Formation, more recent work suggest that it is Upper Cretaceous (Heron, 1978, personal communication).

\section{Middendorf Formation}

The name Middendorf was first used by Sloan (1904) in South Carolina for sands and kaolinitic clays. Although abandoned by Cooke (1936) in favor of the term Tuscaloosa, Heron (1958) favored a formational rank for the unit. Swift and Heron (1969) formally proposed that the Middendorf Formation be recognized forr beds berween the "Hamburg" (Cape Fear Formation) and the overlying Black Creek Formation. Although Sloan (1904) did not designate a type section, the rallroad cut on the seaboard. Railroad $3.2 \mathrm{~km}$ east of Middendort (Chesterfield County, 5. C.) Is generally accepted as the type section. The Middendorf Formation disconformably overlies the Cape Fear Formation and is gradational with the overlying Black Creek Formation. Locally, Cenozoic sediments ranging in age from Eocene to Recent overlie the Middendorf Formation.

The Middendorf Formation is a fluvial unit that crops out in the upper Coastal Plain from just north of Darlington, South Carolina to just south of Fayetteville, North Carolina; it is generally above the Orangeburg scarp. The Middendorf probably does not exceed $70 \mathrm{~m}$ in thickness (Swift and Heron, 1969). It is composed of argillaceous sand with lenses of mudstone and discontinuous conglomerate. Loose to poorly indurated, generally cross-bedded quartz wackes with basal conglomerate are the main sediment type, and kaolinitic clay is the dominant matrix component (Heron and Wheeler, 1964). Because fossil leaves, clay, pebbles, channeling, local disconformities, point bar, and channel fill deposits can be identified, the formation is believed to be of fluvial origin (Heron, 1958).

The Middendorf Formation contains a well known and abundant flora (Berry, 1914; Dorf, 1952) and is considered Coniacian and Santonian in age.

B1ack Creek Formation

The Black Creek Formation is a transitional unit between the Middendorf Formation and the marine Peedee Formation. The formation was named by Sloan (1907) for exposures along Black Creek in Florence and Darlington counties, South Carolina. The Black Creek outcrop belt is principally restricted to the areas between the Orangeburg and Surry scarps. The formation has an estimated average thickness of $100 \mathrm{~m}$, but may reach greater than $200 \mathrm{~m}$ near the coast in the subsurface (Benson, 1968).

The Black Creek Formation conformably overlies and interfingers with 
the Middendorf Formation (Swift and Heron, 1969) and is characterized by laminated dark gray clay intercalated with gray to yellow-orange sand that is often cross-bedded. The claystones of the Black Creek form the. bulk of the formation (Heron and Wheeler, 1964). The formation contains abundant lignitized wood and less abundant sulfide aggregates.' A complex of unusual stratification give the formation a striking appearance. Generally, the formation is easily recognized by the alternation of sand and mud strata. The sediments represent deposition in estuarine, lagoonal and 1ittoral environments (Benson, 1968).

The Black Creek contains a flora of Austin and Taylor age (Dorf, 1952) that is essentially synchronous with plant mega-fossils from the Middendorf Formation (Berry, 1914; Dorf, 1952). Wolfe (1976) found palynomorph assemblages in the upper part of the Black Creek that are assignable to his $\mathrm{CA}-3$ to $\mathrm{CA}-5$ zones. These zones range from lower to upper Campanian (Taylor).

\section{Peedee Formation}

Edmund Ruffin named the Peedee Formation in 1843; Sloan (1908) designated the type locality as Burches Ferry, $16 \mathrm{~km}$ south of the U.S. Route 301 bridge over the Pee Dee River. Although the Peedee Formation disconformably overlies the Black Creek Formation (Benson, 1968), recent workers suggest that the Black Creek-Peedee Formations represent a conformable, transgressive sequence with an interfingering formational contact (Woole and Colquhoun, 1977). The Peedee Formation crops out along the Cape Fear and the Pee Dee Rivers in the eastern part of the Florence Quadrangle. The unit has a thickness ranging from a feather edge in the west to a maximum of $260 \mathrm{~m}$ east in the subsurface.

The Peedee Formation is a neritic, dark micaceous, argillaceous sand characterized by an abundant molluscan fauna (Stephenson, 1923). Although the unit is generally considered highly glauconitic, glauconite usually forms less than 1 percent of the sands.

Swift (1964) undertook the most extensive study of the Peedee Formation and concluded that it was deposited on an open shelf where extensive reworking by infauna occurred. He divided the Peedee into two depositional units: an inner shelf suite composed of sand and muddy sand representing the lower Peedee and an outer shelf suite composed principally of calcareous muddy sand and sandy mud representing the upper Peedee. Swift (1964) also recognized several lenses of biomicrite and biomicrudite.

At the top of the Peedee Formation, a carbonate called the Rocky Point Member occurs. The Rocky Point occurs north of the lape Fear arch in eastern Brunswick and New Hanover Counties, and interfingers with the Peedee Formation. The upper surface of the unit forms the CretaceousTertiary boundary and is an irregular disconformity. It is marked by solution cavities, generally coated with phosphate and minor glauconite: The Rocky Point Member ranges in thickness to a maximum of $27 \mathrm{~m}$ in southern New Hanover Cuunty and represents nearshore deposition in a marine environment of normal salinity. 
The Peedee Formation is Campanian and Maestrichtian; the Rocky. Point has been dated radiometrically with glauconites at $68.1 \pm 1$ m.y. (Harris, 1976).

\section{Black Mingo Formation}

The Black Mingo Formation was first recognized by Sloan (1907) in exposures along the Black River from Brewington Lake, Clarendon County, S. C. to the mouth of Black Mingo Creek, Georgetown County, S. C., Cooke (1936). It referred to all Eocene strata older than the McBean Formation (middle Eocene) as the Black Mingo Formation. The Black Mingo only crops out in the southwest part of the Florence quadrangle at one locality. Its thickness is unknown.

The Black Mingo Formation consists of quartz sand, commonly glauconitic, thin layers of gray to light green silty clay, and dark-gray opal mudstone. Downdip, well-indurated light gray fossiliferous limestone is present. The lithology and fauna indicate that the updip facies of the Black Mingo was deposited in estaurine, tidal flat, and littoral environments. In the lower Coastal Plain, the glauconitic sands and fossiliferous limestone suggest a normal shallow shelf environment.

Cooke (1936) assigned the Black Mingo Formation to the lower Eocene on the basis of mollusks. Cooke and MacNeil (1952) suggested the unit may include beds of Paleocene and early Eocene age. Most recent workers believe that the Black Mingo is a time-transgressive unit with its basal part Paleocene and its upper part lower Eocene (Colquhoun and others, 1969).

Castle Hayne Limestone

The Castle Hayne Limestone was named by Miller (1912) for "exposures in the vicinity of the town of Gastle Hayne." The type section was designated the Martin-Marietta quarry, located approximately $4.5 \mathrm{~km}$ northeast of Castle Hayne, North Carolina by Baum and others (1978a). The Castle Hayne Limestone has a maximum thickness of $11 \mathrm{~m}$ and is present in outcrop only in Duplin County and in the subsurface of the extreme eastern part of Brunswick County. The Castle Hayne Limestone consists of two facies, each characterized by bryozoans and sponges. In New Hanover County, portions of the section are partially to completely dolomitized.

The Castle Hayne Limestone has a well-documented and characteristic fauna. Although Brown and others (1972) consider the unit Claiborne in age, most workers (Canu and Bassler, 1920; Kellum, 1925; Cooke, 1959; and Harris, 1978a) consider the unit latestmost Eocene or Jacksonian in age.

Unnamed Oligocene

Although rocks of 01igocene age have not been mapped in the Florence quadrangle, a small exposure of possible 0ligocene, which crops out along Royal Oak Swamp, Brunswick County, North Carolina, suggests that 01igocene may underlie the extreme southeastern corner of the quadrangle. Brown and others (1972) map Oligocene in this area of Brunswick County. 
Duplin Formation

The Duplin Formation was first referred to as the Duplin "mar:" by Cooke (1936). DuBar (1971) proposed the name Duplin Formation be formally accepted for the unit. An exposure at Natural Well, near Magnolia, , , Duplin County, North Carolina has generally been accepted as the type section. The Duplin Formation occurs throughout the quadrangle as isolated patches (outliers). overlying a dissected Cretaceous or Paleogene surface. However, southward in Darlington, Florence, and Lee Counties, South Carolina, fossiliferous Duplin sands form a thin, nearly continuous layer 3 to $6 \mathrm{~m}$ in thickness.

The Duplin is characteristically sandy limestone; silty, nearly pure soft limestone; and calcareous silty sand. Well preserved fossils of foraminiferas, ostracods, and mollusks are common. Subarkosic and quartzose sands and clays which form interfluve surfaces between the Mechanicsville and Surry scarps are correlated with the Duplin Formation by DuBar and others (1974a). These beds, which appear gradational with. the underlying Duplin, are informally referred to as the "Marietta unit." Because these beds have been considered by most workers as surficial, they are not mapped as a distinct formation on the geologic map. . The maximum thickness of the Marietta is $20 \mathrm{~m}$.

The Duplin Formation is generally regarded as late Miocene (Cooke, 1936; Richards, 1950; and Copeland, 1964); however, recent work by duBar and others (1974a) suggests that this unit is Plfocene in age.

\section{Bear Bluff Formation}

The name Bear Bluff Formation was proposed by DuBar and others (1974a) for a sequence of calcareous sandstone, sandy limestone, subarkosic sand, and calcareous silt that occurs east of the Surry Scarp. The type section is located on the east bank of the Waccamaw River at Bear Bluff, approximately $3 \mathrm{~km}$ east of Conway, Horry County, South Carolina.

The Bear Bluff Formation occurs in the subsurface from southeastern North Carolina to the Santee River of South Carolina. The maximum thickness is unknown, but where the unit occurs in lows on the underlying Peedee and Duplin Formations, its thickness commonly exceeds $30 \mathrm{~m}$. The Bear Bluff Formation is either late Pliocene or early Pleistocene (DuBar and others, 1974a). Because it is often impossible to distinguish Bear Bluff sediments from the overlying Waccamaw Formation, it is included with the Waccamaw on the geologic map.

\section{Waccamaw Formation}

The Waccamaw Formation was named by Dall and Harris (1892). for fossiliferous marine deposits exposed along the banks of the Waccamaw River in Horry County, South Carolina. The Waccamaw occurs as outliers in the outer Coastal Plain from the Cape Fear. River southward to the vicinity of Charleston, South Carolina. The thickness of the Waccamaw varies from a feather edge to a maximum of about $16 \mathrm{~m}$ in the subsurface (Howard, 1974). The Waccamaw Formation consists of poorly sorted to moderately well-sorted, semi-indurated, fine to coarse sand. Carbonate content is mostly in the form of fossil shells. Unweathered sediments 
are light blue; weathered sediments are yellowish brown to deep reddish brown. In some areas, these deposits grade upward to generally unfossiliferous sediments. Locally, a thin unit of quartz and phosphate pebbles and coarse sand forms the base of the Waccamaw. Waccamaw fauna are we11-preserved and abundant, and they indicate brackish-water and shallow marine shelf.

The Waccamaw Formation age has been disputed by numerous workers. Most early workers considered the Waccamaw to be Pliocene; however, recent work by DuBar and others (1974a) and Zullo and Harris (1978) suggests a Pleistocene age.

\section{Canepatch Formation}

The name Canepatch Formation was proposed by DuBar and others (1974a) for complex deposits of sand, clay, silt, and peat exposed along the Intracoastal Waterway in Horry County, S.C. The type section is located on the south bank of the waterway near Canepatch Swamp, approximately $10.4 \mathrm{~km}$ northeast of Myrtle Beach. The unit only occurs in the extreme southeast corner of the Florence quadrangle, along the west bank of the Cape Fear River. The formation reaches a maximum thickness of about $23 \mathrm{~m}$, but averages only about $10 \mathrm{~m}$. Dominant lithologies are: cross-bedded, humate impregnated sand; fossiliferous clayey sand; blue fossiliferous sandy clay; dark brown sand and clayey sand and peaty clay; and beach rock (coquina).

The Canepatch Formation contains an abundant and we11-described fauna (DuBar and others 1974a) that suggests an interglacial origin..for the formation. Radiocarbon dates of cypress.wood, the coral Septastrea crassa, and the pelecypod Mercenaria campehiensis, from Horry County by the radiocarbon method and obtained an age of $31,810+785$ years.

\section{Post-Canepatch Units}

Modern floodplain and Pleistocone fluvial terrace deposits oscur along Lynches, Pee Dee, Little Pee Dee, Lumber, Waccamaw, and Cape Fear Rivers. These units are herein grouped together because of their similarity in lithology and origin and their geographical position along the major drainage systems. These sediments are principaliy humate-rich sand, sandy silt, and silty clay. Their thickness is highly variable, ranging from about 6 to $20 \mathrm{~m}$. On the basis of their stratigraphic position, these units range from Holocene for the modern floodplain deposits to medial-late Pleistocene for the oldest terrace deposits.

\section{$\underline{\text { Surficial Deposits }}$}

The Coastal Plain in the Florence quadrangle is covered by a thin veneer of sand and clay that almost everywhere conceals the older formations. Above the Orangeburg scarp, the surface is covered by fluvial and rare eolian sediments classed as high-level gravels, sands, and clays. These high-level surficial deposits have variously been called the Citronelle Formation in the area of the Pee Dee River and Pinehurst Formation in the Sandhills area of North Carolina and are considered Miocene. The Citronelle has a maximum thickness of $33 \mathrm{~m}$ (Doering, 1960); the Pinehurst at the type section in Moore County, approximately $2 \mathrm{~km}$ southeast of West End, is $7 \mathrm{~m}$ thick (Bartlett, 1967). 
Between the Orangeburg and Surry scarps (middle Coastal Plain), three prominent terraces are present: Coharie $(+75 \mathrm{~m})$; Sunderland $(+52 \mathrm{~m})$; and Okefenokee $(+41 \mathrm{~m})$. These plains dip gently oceanward and include primary depositional topography that can be identified as alluvial fans or deltas, and minor landforms such as offshore bars, beach ridges, and meander scars. Terrace sediments in the middle Coastal Plain vary in type and thickness and are considered late Miocene in age.

The lower Coastal Plain (below the Surry scarp) exhibits the effects chiefly of depositional topography, although continental and marine landforms are present. Six terraces have been recognized: the Wicomico, Penholway, Talbot, Pamlico, Princess Anne, and Silver Bluff. Sediments underlying these terraces are variable in type and thickness.

\section{STRUCTURAL GEOLOGY}

The Cape Fear arch in southern North Carolina is the principal structural feature of the Atlantic Coastal Plain Province. It is southeast-plunging basement high extending from the fall line along the Cape Fear River to about Cape Fear. Its axial trace marks the main area of Cretaceous outcrops in North and South Carolina.

Movement of the arch may have occurred as early as Albian or post-Albian pre-Cenomanian time; however, it was local in nature, because Tuscaloosa (Middendorf and Cape Fear) sediments on the arch near the fall line do not show thinning (Bonini and Woolard, 1960). Recurrent movement of the arch has probably occurred during most of the Cenozoic Era (Harris and others, 1979a). Some recent workers have suggested the Cape Fear arch has periodically been active as recent as 75,000 years ago (Zullo and Harris, 1979). There are no other structures in the quadrangle.

\section{MINERAL RESOURCES}

There are no reported occurrences of metallic minerals, mica, pegmatites, or massive sulfides in the quadrangle. There are commercial deposits of non-metallic resources including sand and gravel, stone, and clay.

Sand, gravel, and crushed stone

Sand, grave1, and stone (granite) are mined commercially in Anson, Buncombe, Cumberland, Harnett, and Moore Counties, North Carolina, and Chesterfield, Dillon, Darlington; Florence, and Marlboro Counties, South Carolina. Most produced sand is used in building and construction work. Gravel and crushed stone are used in building, paving, and railroad ballast.

Clay

Clay is quarried in Darlington, Marlboro, and Marion Counties, South Carolina from Pleistocene(?) terrace deposits along the Pee Dee River and its tributaries. This material is used to manufacture brick and drain tile. 
Others

Phosphate and glauconite occurrences in the quadrangle are discussed because they contain traces of uranium and thorium.

Glauconite is a finely-divided micaceous dioctahedral clay mineral rich in iron and potassium and similar to illite. It commonly occurs in concentrations of $20-30 \%$ in some zones within the Peedee, Black Mingo, and Castle Hayne Formations. In addition, it also occurs as a precipitate mixed with phosphate on many Coastal Plain disconformities. Yasyrev (1966) demonstrated that glauconites average $400 \mathrm{ppm}$ thorium and $10 \mathrm{ppm}$ uranium. Therefore, concentration of these two elements may occur under proper conditions of diagenesis.

Allluugh phusphates are not mined in the quadrangle, Teyas fin.1 $\mathrm{f}$ Sulphur Company operates a large mine in Beaufort Councy, N.C. Becâuse trace amounts of uranium have been found uniformly distributed with the phosphate grains at this deposit; undiscovered phosphate deposits in the Florence quadrangle may be enriched in uranium and thorlüm. Phosphate deposits have been described in South Carolina by Rogers (1914) and Watkins (1937), and in the Charleston area by Malde (1959). The generalized geology of the quadrangle is shown on Plare 1.

GEOLOGIC LITERATURE FOR THE FLORENCE AREA

Previous Studies

Recent geologic mapping of the Florence quadrangle is sparse (Figure 1). Only the northwest part of the quadrangle has been mapped since 1958; most previous studies have only concentrated on local problems of stratigraphy, palentology, or petrology. Heron (1958) examined and mapped Cretaceous sediments in the upper Coastal Plain between Lynches River, S. C., and Neuse River, N. C., Jorgenson (1969), Cooley (1970), Waskom (1970), and Monrad (19.72) examined various parts of the western part of the quadrangle (Figure 1). The Coastal Plain in North Carolina below the Orangeburg scarp has been mapped by Stephenson (1923) and Clark and others (1912), and the subsurface by Brown and others (1972). These reports are the only studies that attempt to delineate the surface and subsurface distribution of sediments and rocks in North Carolina as part of the quadrangle. Baum (1977) mapped the Tertiary units in North Carolina east of the quadrangle.

In South Carolina, only the works of Cooke (1936) and DuBar and others (1974a) have delineated the spatial distribution of the surface formations in the quadrangle. Recent surficial deposits have been described by Colquhoun (1974) south of the Cape Fear River. Concentrated studies of specific units have been made by: Swift (1964) - Peedee Formation; Benson (1968) - Black Creek Formation; Ibrahim (1973) - Middendorf; Harris (1975) - Rocky Point Member of Peedee Formation; and Upchurch (1973) Castle Hayne Limestone.

Current Research

The Geology and Mineral Resources Section (GMRS) of the North Carolina 
Department of Natural and Economic Resources has initiated a program to produce reconnaissance geologic maps for the entire state. The state has been divided into 17 multi-county planning regions that will be covered by the maps. The GMRS plans to have open-file reports on the Coasta1 Plain by 1981. Mapping has not yet been started.

Three graduate students at the University of North Carolina at Chapel Hill are currently working on masters' theses of parts of the Florence quadrangle. Roger Shew (under the direction of Roy. L. Ingram) is mapping along the Cape Fear River from just south of Fayetteville to Elizabethtown. He is also examining recent sediments in the river. Suellen Cape (under the direction of Walter $H$. Wheeler) is examining the Citronelle Formation in the inner Coastal Plain from south of Fayetteville to the South Carolina border. Edward Custer (under the direction of Roy L. Ingram) is examining the subsurface distribution environments of the Cretaceous formations in the region of Cape Fear arch.

Duncan Heron, at Duke University, is in the beginning stages of examining the subsurface distribution of the Cretaceous formations along the Cape Fear River. During 1978 he plans to profile the river between Fayetteville and Wilmington.

Donald Colquhoun, University of South Carolina, and several students have been actively examining the Cretaceous geology of Marlboro, Dillon, Marion, and Horry Counties, South Carolina.

James Owens and Blake Blackwelder of the U.S. Geological Survey have been mapping in the Cape Fear - Peedee Rivers region.

Thomas Worsley and two graduate students at Ohio University are examining nannofossils in the Peedee Formation and most Tertiary units in North Carolina.

Victor Zullo and W. Burleigh Harris, at the University of North Carolina at Wilmington, are examining the Pliocene and Pleistocene stratigraphy and paleontology of North and South Carolina.

There are no other current concentrated efforts to map the Florence quadrangle.

\section{GEOLOGIC HISTORY}

The Coastal Plain Physiographic Province extends along the Atlantic Coast from southern Florida to the Grand Banks of Newfoundland. The sediments and sedimentary rocks form a wedge-shaped mass that thickens from a feather edge along the fall line to a maximum along the coast. These sediments and rocks rest unconformably on a Paleozoic and Precambrian basement of igneous and metamorphic rocks. In the western part of the Florence quadrangle, Coastal Plain strata onlap the Carolina Slate Belt. Although the strata range in age from Jurassic(?) to Holocene, only Upper Cretaceous through Holocene sediments and rocks occur in the Coast Plain part of the quadrangle. 
During early Late Cretaceous time, a transgression of the ocean onto the Piedmont surface established a time-transgressive stratigraphic . sequence dominantly representative of three depositional environments: the Cape Fear-Middendorf Formations - fluvial, fluvio-marine; the Black Creek Formation - estaurine, lagoonal, and 1ittora1; and the Peedee. Formation - open marine shelf. Although local disconformities exist between the Cape Fear and Middendorf and the Black Creek and Peedee Formations, formational boundaries are generally intertonguing and suggest the absence of major tectonian or eustatic changes in sea level.

During latest Cretaceous, uplift of the Cape Fear arch established a near shore regressive sequence in the dominantly transgressive regime of the Peedee Formation. This initiated deposition of the shallow marine Rocky Point Member of the Peedee Formation along the Cape Fear arch and north of it. The close of the Mesozoic is marked by regression of the sea dul probably uplift of the Cape Fear arch. The arch appears to have remained high during the entirely of Paleocene deposition, as Paleocene sediments only occur south and north of the arch axis.

The Castle Hayne Limestone represents a major transgression of the sea over Mesozoic and Paleocene sediments and rocks. The Castle Hayne was deposited during the temporal transgression during the middle and late Eocene. In New Hanover County, N.C., the presence of dolomitized sediments in the Castle Hayne, which are thought to have originated through dorag dolomitization, suggest that the Cape Fear arch was active and a positive element. Subsequently, during late Eocene, the Castle Hayne deposition, the sea withdrew from the Coastal Plain and the Cape Fear arch emerged.

A major transgression occurred during the late Miocene or early Pliocene(?) when the Duplin Formation was deposited seaward of the Orangeburg scarp while high-level gravels were deposited west of the scarp. The Duplin transgression resulted in deposition of strata on a dissected surface of late Cretaceous to Paleocene strata. Regression of the Duplin sea may have been a direct result of polar ice cap advance (LuBar and viliers, 1974a) or tectonism (Zu11o and Harris, 1979).

The next major transgression occurred during the late Pliocene-ear1y Pleistocene and resulted in the occupation of the Mechanicsville scarp and deposition of the Marietta-Bear Bluff Formatlons. Marine Bear Blut $f$ sediments extend landward to the Surry scarp; the "Marietta" sands occur between the Surry and Mechanicsville scarps and are considered to be cquivalent to the Bear Bluff Formation. The Bear Bluff sea reached a maximum elevation of about $36.5 \mathrm{~m}$.

Prior to Waccamaw submergence, the Duplin, Marietta, and Bear Bluff formations were subjected to a significant period of erosion. During the Pleistocene, the Waccamaw sea rose to a maximun level of about $30 \mathrm{~m}$, occupying the Surry scarp.

The Bear Bluff and Waccamaw seas never transgressed north of Cape Fear River, and are therefore restricted to the area south of the Cape 
Fear River and a narrow zone along the North Carolina coast. Withdrawal of the Waccamaw sea from the Coastal Plain was followed by the less extensive Canepatch transgression that occupied part of the unelevated outer Coastal Plain. This transgression probably occurred during the Sangamon stage. The Canepatch sea withdrew at the end of the Sangamon (75,000 years ago) and was followed by uplift along the Cape Fear River. This resulted in elevation of the area southwest of the Cape Fear River and formation of terrace deposits along the Pee Dee, Little Pee Dee Lumber, and Waccamaw Rivers. 


\section{THIS PAGE}

\section{WAS INTENTIONALLY \\ LEFT BLANK}


GEOLOGY AND MINERAL RESOUIRCES OF THE

BEAUFORT

$1^{\circ} \times 2^{\circ}$ NTMS QUADRANGLE 


\section{THIS PAGE \\ WAS INTENTIONALLY \\ LEFT BLANK}

$$
26 .
$$


Location and Physical Geography 28

Stratigraphy 28

Cretaceous 28

Tertiary 29

Structural Geology 36

Mineral Resources 37

Geologic Literature For The Beaufort Quadrangle 38

Geologic History 39 
The Beaufort $1^{\circ} \times 2^{\circ}$ NTMS quadrangle covers about $20,000 \mathrm{sq} \mathrm{km}$ in North Carolina, of which about $9,500 \mathrm{sq} \mathrm{km}$ are land area and 10,500 sq $\mathrm{km}$ are ocean. The land part of the quadrangle is located entirely in the Atlantic Coastal Plain Province. Elevations range from greater than $30 \mathrm{~m}$ in the extreme northwestern part to sea level in the eastern part of the quadrangle. Rainfall averages $132 \mathrm{~cm}$ per year in Wilmington, the largest city. Temperatures are moderate, with the norma1 $26.44{ }^{\circ} \mathrm{C}$. in July and $7.28{ }^{\circ} \mathrm{C}$ in January. Dense vegetation, low relief and the existence of a thin veneer of surficial sand, and a deeply weathered soil profile make geologic mapping difficult.

The quadrangle is physically divisible into two distinct parts: The middle Coastal Plain extends from the Coats. (Orangeburg) scarp $(75 \mathrm{~m})$ to the Surry scarp $(33 \mathrm{~m})$. The lower Coastal Plain extends from the Surry scarp to the coastal margin. Although the Surry scarp (33 $\mathrm{m}$ ) is commonly shown about $70 \mathrm{~km}$ inland paralleling the coastline between Cape Lookout and Cape fear (Vaniels, and othèrs, 1972), Zullo and Harr1s (1978) suggested that the Surry scarp extended south from about Pink Hil1. (Lenoir County) to about the New River at Jacksonville and turned southwest to join the Hanover scarp. The middle and lower Coastal Plains are characterized by differing combinations of primary depositional features and subsequent erosion features.

A vast system of creeks and rivers of two major types drains the quadrangle. Heading in the Piedmont are the Cape Fear and Neuse Rivers, which drain the southern and northern part of the quadrangle, respectively. Heading in the Coastal Plain and draining the central part of the quadrangle are the Northeast Cape Fear, New, and Whiteoak Rivers. The quadrangle is gently rolling to flat with steepest topography usually adjacent to major drainage systems.

\section{STRATIGRAPHYY}

\section{CRETACEOUS}

\section{Peedee Formation}

The Peedee Formation was named by Ruffin in 1843; Sloan (1908) designated the type locality as Burches Ferry, $16 \mathrm{~km}$ south of the U.S. Route 301 bridge over the Peedee River, Florence County, South Carolina. The Peedee Formation represents the oldest strata present in the Beaufort quadrangle. It crops out along the Northeast Cape Fear River in the western part of New Hanover, Pender, and Duplin Counties, and is present in the subsurface of the eastern part of the quadrangle. The unit reaches its maximum thickness of greater than $100 \mathrm{~m}$ in the subsurface of New Hanover and eastern Onslow Counties.

The Peedee Formation is a massive neritic, dark micaceous, argillaceous sand characterized by an abundant molluscan fauna (Stephenson, 1923). Glauconite forms a minor constituent of the unit. 
Swift (1964) undertook the most extensive study of the Peedee. Formation and concluded that it was deposited on an open shelf where extensive reworking by infauna occurred. He divided the Peedee into two depositional units, an inner shelf suite composed of sand and muddy sand representing the lower Peedee and an outer shelf suite composed principally of calcareous muddy sand and sandy mud representing the upper Peedee. Swift (1964) also recognized several lenses of biomicrite and biomicrudite. On the basis of mega- and microfauna the Peedee Formation is Campanian to Maestrichtian (Upper Cretaceous).

Rocky Point Member

The top of the Peedee Formation north of the Cape Fear arch is characterized by a carbonate called the Rocky Point Member. Although it occurs in eastern Brunswick, New Hanover, eastern Pender, and southern Onslow Counties, it crops out only in northern New Hanover County along the northeast Cape Fear River. The unit occurs directly below the Mesozoic-Cenozoic boundary to the west and interfingers and underlies typical Peedee lithology to the east. The Rocky Point Member consists of four principal lithologies: lower quartz arenite; upper sandy, pelecypod biosparrudite; sandy, pelecypod biosparite; and sandy biosparite. These last three lithologies form lateral, time-equivalent facies. The Rocky Point Member represents deposition in a nearshore marine environment of normal salinity. It ranges in thickness to a maximum of $27 \mathrm{~m}$ in the subsurface of southern New Hanover County.

The Rocky Point Member contains an Upper Cretaceous megafauna and a Campanian and Maestrichtian for aminifera microfauna. Most microfauna are restricted to the Maestrichtian stage. Glauconites from the Rocky Point Member and stratigraphically equivalent Peedee sediments have been dated by the $\mathrm{Rb}-\mathrm{Sr}$ isochron method at $68.1 \pm 1 \mathrm{~m} . \mathrm{y}$. by Harris (1976).

\section{TERTIARY}

\section{Beaufort Formation}

'I'he Beaufort Formation only occurs in the subsurface of the quadrangle; however, because it may be present in outcrop it is discussed. The Paleocene Beaufort Formation was unrecognized in outcrop when Brown (1958) named the unit from a well drilled at Chocawinity (Beaufort County), North Carolina. The Beaufort Formation includes mudstone that intergrades with chert, mudstone-chert intercalated with sandstone (Jericho Run Member), glauconitic sand, and phosphatic conglomerate (Brown and others, 1977). Mudstone and siliceous mudstone showing significant quantities of disordered cristobalite and opal are the dominant rock type and characterize the lower Beaufort Formation. Unconsolidated, sandy, forminifera1glauconitic sediments alternating with thinner, slightly glauconitic, formainiferal biomicrosparites characterize the upper Beaufort Formation. The unit obtains a maximum thickness in the subsurface of approximately $46 \mathrm{~m}$ in eastern Carteret County (Brown and others, 1972).

The siliceous mudstone and basal phosphate-pebble conglomerate of the lower Beaufort (Danian) were deposited in the inner neritic environment 
(Carlson, 1976). Thanetian sediments were deposited in a normal marine environment that ranged from inner to middle neritic.

Based on the planktic foramintfera, the siliceous mudstone belongs to Berggrens' (1972) P1 zone which is early Danian. Planktic foraminifera from the upper unconsolidated glauconitic sediments belong to Berggrens' (1972) P4 zone which is Thanetian. In addition, $\mathrm{Rb}-\mathrm{Sr}$ glauconite ages of 55.7 and $57.8 \mathrm{M} . \mathrm{Y}$. from these sediments support a Thanetian age for the upper glauconitic sand (Harris and Baum, 1977).

Castle Hayne Limestone

The Castle Hayne Limestone was named by Miller (1912) for "exposures in the vicinity of the town of Castle Hayne." The type section was designated the Martin Marietta quarry, located approximately $6 \mathrm{~km}$ northeast of Castle Hayne, North Carolina was designated the type section by Ward and others (1978). The Castle Hayne Limestone is present in outcrop in western New Hanover, central and northern Pender, northwestern Onslow, and eastern Duplin Counties. In Duplin County, it occurs oniy as outliers. The unit is also present in the subsurface of New Hanover, Pender, Onslow, Jones, Craven, and Carteret Counties.

The Castle Hayne Limestone has a maximum outcrop thickness of $11 \mathrm{~m}$ and subsurface thickness in eastern Carteret County of about $250 \mathrm{~m}$. It is divided by Baum and others (1978a) into three 1ithofacies: 1ower phosphate pebble conglomerate, middle bryozoan blosparrudite, and upper bryozoan biomicrudite. In New Hanover County, parts of the formation are partially to completely dolomitized (Baum and others, 1978b) and contain abundant sponges (Upchurch, 1973).

The Castle Hayne Limestone contains an abundance of stenohaline fauna typical of a warm tcmpcratc to tropical marine environment; theretere it was deposited in an open environment of normal salinity. Based on the assemblages of bryozoans, mollusks, crinoids, and other faunal elements, Baum (1977) suggested that the bryozoan blomicrudice facles was depusiled in water depths of $30-50 \mathrm{~m}$. As the bryzoan biosparrudite facies occurs updip and shoreward, Baum (1977) suggested that it was deposited in-water depths less than $30 \mathrm{~m}$.

The Castle Hayne Limestone has a well-documented and characteristic fauna, although Brown and others (1972) and Baum and others (1978a;

1979b) consider the unit Claibornian, Canu and Bassler (1920), Kellum (1925), Cooke (1959), and llarria and nthera (1979b) consider the . unit late Eocene or Jacksonian. The Castle Hayne Limestone probably transgresses the Claibornian and Jacksonian. Harris and others (1979b) determined a late Jacksonian age $(34.8 \pm 1 \mathrm{m.y.})$ for the bryozoan biomicrudite lithofacies at the Martin Marietta quarry, based on $\mathrm{Rb}-\mathrm{Sr}$ dates of glauconite.

$\underline{\text { New Bern Formation }}$

The New Bern Formation was named for a predominantly sandy, pelecypod-mold biomicrosparrudite that disconformably overlies the Castle Hayne Limestone in the Martin Marietta quarry at New Bern, 
Craven County, North Carolina by Baum and others (1978a). This same unit is considered by Ward and others (1978) as the Spring Garden Member of the Castle Hayne Limestone. The New Bern Formation crops out only in the northern part of the quadrangle in Jones County but probably occurs in the subsurface of eastern Onslow and Jones Counties and in Carteret and Craven Counties. At the type section, the New Bern Formation is about $9 \mathrm{~m}$ thick and consists of three 1ithologies: lower calcareous quartz arenite; sandy, fine, pelecypod-mold biomicrosparrudite; and sandy, medium to coarse, pelecypod-mold biomicrosparrudite.

The New Bern Formation was deposited in a transgressive depositional system ranging from intertidal in the lower part through a sandy, continental shelf at depths of $7-40 \mathrm{~m}$ in the upper part. The fauna suggest a warm temperate marine environment.

Because diagnostic fossils do not occur in the New Bern Formation; and because the formation is disconformably overlain by the oligocene Trent Formation, the New Bern is assigned a latest Jacksonian age.

\section{Trent Formation}

The type section of the Trent Formation was designated the Trent River from New Bern to Trenton (Miller, 1912); however, because the section contains two distinct formations, Baum and others (1978a) restricted the Trent Formation to the outcrops occurring along the river from New Bern to within $0.7 \mathrm{~km}$ of Pollocksville (Jones County). Ward and others (1978) named this same unit the River Bend Formation and designated the series of limestones that occur $0.3 \mathrm{~km}$ above Rhems Landing at River Bend Estates along the Trent River, Craven County, North Carolina, the type section. The Trent Formation disconformably overlies the New Bern Formation.

The Trent Formation is confined to the areas between the Neuse and New Rivers and crops out only in a narrow northeast trending belt in central Onslow and eastern Jones Counties. It probably occurs in the subsurface of eastern Onslow, Jones, and Carteret Counties.

The Trent Formation consists of three 1ithologies: 1ower, sandy, echinoid biosparite; sandy, pelecpypod-mold biomicrudite; and barnacle, pelecypod-mold biosparrudite. The formation has an approximate thickness of 9-10 $\mathrm{m}$ along the Trent River, Craven County.

The Trent Formation represents a transgressive-regressive sequence that was deposited in a warm-temperature marine environment. The basal part was deposited in the intertidal zone, the middle on a sandy, continental shelf at depths of $7-40 \mathrm{~m}$. The upper part was deposited during regression of the seas, in a shallow marine environment. Because of the concurrence of Oligocene to recent mollusks and Eocene to Oligocene barnacles, the Trent Formation is considered Oligocene age (Baum and others, 1978a). 
Belgrade and Silverdale Formations

The basal $7.5 \mathrm{~m}$ of the Martin Marietta quarry located south of the Whiteoak River in the town of Belgrade, Onslow County, was designated the type section of the Belgrade Formation by Baum and others (1978a). Ward and others (1978) regard this lower section the upper part of their 01igocene River Bend Formation. The two principal lithologies of the Belgrade Formation are lower unconsolidated quartz arenite about $2.5 \mathrm{~m}$ thick, grading upward into $5.5 \mathrm{~m}$ of sandy, pelecypod-mold biomicrudite. Disconformably overlying the Belgrade Formation are channel sands containing Crassostrea gigantissima and an abundant molluscan fauna which grade upward into clay. These lithologies are approximately $2 \mathrm{~m}$ thick and are regarded by Baum and others $(1978 \mathrm{a} ; 1.979 \mathrm{~b})$ as equivalent to their Silverdale Formation. Ward and others (1978) consider this section the Haywood Landing Member of their Belgrade Formation, and consider the member as a contempnranenus facles of the Crassostrea beds.

The quarry located just east of the city of Silverdale, Onslow County, was designated by Baum and others (1978a) the type section of the Silverdale Formation. The Silverdale consists of two lithologies: a basal $0.8 \mathrm{~m}$ dense, sandy, pelecypod-mold biomicrudite which grades upward into $2.4 \mathrm{~m}$ of an unconsolidated, sandy, pelecypod biomicrudite.

The Belgrade and Silverdale Formations disconformably overlie the Trent Formation and occur in eastern Pender, eastern Onslow, eastern Craven, and Carteret Counties. They do not crop out naturally, and exposures are apparently restricted to active quarries. The Belgrade and Silverdale Formations represent depositions on a sandy, continental shelf in normal marine waters. Parts of the Silverdale Formation . (Crassostrea beds) suggest lagoonal brackish water environments.

The Silverdale formation has a well documented Miocene age (Kellum, 1925, 1926; Richards, 1948; Vokes, 196\%, 1970). Because barnacles that occur in the Silverdale Formation are conspecific with barnacles found in the Belgrade Formation, the Belgrade and Silverdale Formations probably represent two laterally equivalent depositional facies. Therefore, the Belgrade and Silverdale Formations are considered Miocene in age (Baum and others, 1978a).

\section{Pungo River Formation}

Kimrey (1964) proposed the name Pungo River Formation for middle Miocene phosphat1c sediments firsl descriled by brown (1958) 1n the subsurface of Beaufort County. A core hole located at $76^{\circ} 34^{\prime} 59^{\prime \prime} \mathrm{W}$, $35^{\circ} 35^{\prime} 58^{\prime \prime} \mathrm{N}$, Beaufort County, was chosen as the type section. The Pungo River Formation occurs as an outlier in Carteret County and in the subsurface of Pamlico and Carteret Counties.

The chief lithologies of the Pungo River Formation are 1ight-green diatomaceous clay and fine- to medium-grained quartz sand containing varying amounts of greenish-brown clay and light- to dark-brown collophane. Light olive-green dolomite and dolomitic limestone, white to light gray molluscan limestone, calcareous clay, shell hash, and 
chalk are less abundant constituents. In the Beaufort quadrangle, the Pungo River Formation reaches a maximum thickness of about $45 \mathrm{~m}$ in the subsurface of eastern Carteret County.

The Pungo River Formation was deposited in an open marine, normal salinity, shallow shelf environment with water temperatures cool to cool-temperate. Gibson (1967) concluded that most of the unit was deposited in water $100-200 \mathrm{~m}$ deep.

The Pungo River Formation is considered correlative with the middle Miocene Calvert Formation of Maryland on the basis of benthic foraminifera (Brown, 1958). Gibson (1967) also concluded the formation was middle Miocene on the basis of mollusks and benthic foraminifera.

\section{Duplin and Yorktown Formations}

The Duplin Formation was first referred to formally in North Carolina by Miller (1912). Although he stated that the Yorktown and the Duplin Formations occupied the same stratigraphic position, because of differences in the fauna they should not be referred to as a single formation. Although the type section was not designated, the exposure at Natural Well, approximately $3 \mathrm{~km}$ southwest of Magnolia, Duplin County, is regarded the type section.

The Duplin Formation occurs as isolated outliers in New Hanover, Pender, Duplin, and Onslow Counties. It overlies a dissected Cretaceous, Eocene, and Miocene surface.

The Duplin Formation consists. of fine quartz sand and bluish-green argillaceous sand with abundant mollusks. The mollusks are well worn and broken as well as unworn and whole. South of the Cape Fear River, the Duplin Formation is characteristically a sandy limestone; silty, nearly pure soft limestone; and calcareous silty sand.

The Yorktown Formation was named by Clark and Miller (1906) for exposures of fossiliferous sand and clay on the York River at Yorktown, Virginia. The Yorktown Formation is characterized by its abundant and varicd fauna and hac becn divided into four membero in the Virginia Coastal Plain by Blackwelder and Ward (1976). Although these members can be traced into northeastern North Carolina to the Neuse River, they have not been mapped. South of the Neuse River, the discontinuous nature of Yorktown beds precludes their recognition.

In the northern part of the Beaufort quadrangle, the Yorktown Formation consists of bluish to greenish gray, clayey quartz sand and interbedded clay and sandy clay beds that contain an abundant fauna. Because of the lithological similarity of the Duplin Formation to the Yorktown Formation, and because the Duplin Formation is the same age as the Yorktown Formation, Blackwelder and Ward (1979) proposed that the term Duplin Formation be abandoned and that the beds formally assigned to it be called Yorktown. The thickness of the Duplin and Yorktown Formations probably is about 2-3 $\mathrm{m}$ in outcrop and $45 \mathrm{~m}$ in the subsurface of eastern Carteret County. 
The Duplin and Yorktown Formations represent deposition in a warm-temperate climatic zone. Specific environments are shallow. marine bars, lagoons, and a sandy, continental shelf in water depth 23 to $46 \mathrm{~m}$.

The Duplin and Yorktown Formations have traditionally been regarded as late Miocene (Cooke, 1936; Richards, 1950; and Copeland, 1964); however, recent work by DuBar and others (1974a, b), and Blackwelder and Ward (1979) suggests that the Duplin and Yorktown Formations are P1iocene.

\section{Waccamaw and James City Formations}

The Waccamaw Formation was named by Dall and Harris (1892) for fossiliferous marine deposits exposed along the banks of the Waccamaw River in Horry County, South Carolina. It occurs in a nearly continuous outcrop belt in the outer Coastal Plain from Brunswick to Carteret Counties (east of the Hanover and Surry scarps). The Waccamaw Formation ranges up to $15 \mathrm{~m}$ in thickness in the subsurface.

The Waccamaw consists of poorly to moderately well sorted, semi-indurated, fine to coarse fossiliferous sand. Unweathered sediments are light blue; weathered sediments are yellowish brown to deep reddish brown. In some areas these deposits grade into generally unfossiliferous sediments. Locally, a thin unit consisting of quartz and phosphate pebbles and coarse sand forms the base of the Waccamaw.

The formation contains an abundant molluscan fauna that probably exceeds 500 species (Campbell and others, 1975). The abundant, well-preserved Waccamaw fauna are indicative of a warm-temperate brackish-water and a shallow marine shelf environment.

Numerous workers have disputed the age of the Waccamaw Formation. Most early workers considered the unit Pliocene; however, DuBar and others (1974a) Zu11o and Harris (1978) suggest an early Pleistocene age for the unit. Campbell and others (1975) favored a late Pliocene age based on correlation with the radiometrically dated Caloosahatchee Formation of south Florida.

Fossilferous marine sediments at the same stratigraphic horizon that occur north of New River and east of the Hanover scarp are referred to as the James City Formation. The James City Formation was described by DuBar and Solliday (1963) from strata exposed along the banks of the Neuse River estuary near the town of James City, Craven County, North Carolina. It includes part of the Croatan Formation of previous workers. The fauna of the James City Formation is correlated with that of the Waccamaw Formation; therefore, the two units are considered equivalent.

The James City Formation consists of slight1y to moderately indurated, very fine quartz sand, silt, and clay. An abundant, well preserved molluscan fauna is usually present; however, in places all carbonate has been dissolved and fossil molds are present.

Because the Waccamaw and James City formations occupy the same stratigraphic interval, and are of similar lithology, they are grouped together on the geologic map. 
The Canepatch Formation was proposed by DuBar and others (1974a) for complex deposits of sand, clay, silt, and peat exposed along the Intracoastal Waterway in Horry County, South Carolina. This unit only occurs in the extreme southern part of the quadrangle along the Cape Fear River and Intracoastal Waterway. The formation reaches a maximum thickness of about $23 \mathrm{~m}$, but averages only about $10 \mathrm{~m}$.

The Canepatch Formation consists of the following dominant 1ithologies: cross-bedded, humate impregnated sand; fossiliferous clayey sand; blue fossiliferous sandy clay; dark brown sand; and clayey sand and peaty clay. Beach rock coquina is also common. The Canepatch Formation contains an abundant and well-described fauna (DuBar and others, 1974a) that. suggest an interglacial origin for the formation.

Radiocarbon dated cypress wood, the coral Septastrea crassa, and the pelecypod Mercenaria campechensis from the Canepatch Formation yielded ages greater than 35, 000 years for the unit (DuBar and others, 1974a). Zullo and Harris (1978) dated a Mercanaria campechensis from the type Canepatch and obtained a radiocarbon age of $31,810 \pm 785$ years. A Mercenaria campechensis specimen from equivalent material at Burnett, New Hanover County, yielded a radiocarbon age of 39,040 \pm 1800 years.

The Flanner Beach Formation was first described by DuBar and Solliday (1963) from exposures along the Neuse River at Flanner Beach, Craven County. It here includes the Newport sand, Arapahoe sand, Minnesott sand, and Beard Creek member of Mixon and Pilkey (1976). The Flanner Beach Formation consists of. slightly indurated very fine to fine sand with minor medium to coarse sand and some silt and clay. The upper part of the unit is characterized by cross-stratification. Calcium carbonate comprises 20 percent or more of some lithologies and is mainly in the form of pelecypods and gastropods. The maximum thickness of the Flanner Beach Formation is $10 \mathrm{~m}$.

Flanner Beach sediments represent deposition in a barrier-island, lagoonal complex. Therefore, fauna and sediments represent brackish to normal marine waters. The Flanner Beach Formation is considered medial Pleistocene and equivalent to the Canepatch Formation of the southern part of North Carolina.

Because the Canepatch and Flanner Beach Formations and the Waccamaw and James City Formations represent a short span of geologic time and are lithologically similar and have not been separated throughout most of the area, they are grouped together as Q-T on the geologic map.

Undifferentiated Late Pleistocene and Holocene Sediments

Undifferentiated late Pleistocene sediments include the Core Creek sand, the Atlantic sand, Cedar Island sand, North Bay sand, Bogue sand, and Beaufort sand of Mixon and Pilkey (1976). Also included in this category are the Socastee Formation of DuBar and others (1974a) which is restricted to the area south of the Cape Fear River and the "Cherry Point unit" of DuBar and others (1974b), which is restricted to the area of the Neuse River. 
The sediments occur east of the Suffolk or Bogue scarps. They consist dominantly of silty and clayey fossiliferous sand, very pale gray to light greenish-gray, fine to medium nonfossiliferous quartz sand, and associated silty and clayey sands which vary in thickness.

Holocene sediments include beach and dune sand and fossiliferous sand, soft silty and clayey mud, and peat that occur along the barrier islands and the sounds. They are not differentiated from late

Pleistocene sediments.

\section{$\underline{\text { Surficial Deposits }}$}

The middle and lower Coastal Plain in the quadrangle is covered by a thin veneer of grave1, sand, silt, and clay that almost everywhere conceals the older formations. I'he middle Coastal Plain Includes lite area between the Coats (Orangeburg) scarp and the Surry scarp, and consists of three seaward sloping terrace plafins separated by lié wilson Mills scarp $(65.5 \mathrm{~m})$ and the Kenly scarp $(45 \mathrm{~m})$. These three plains, which form the bulk of the surficial deposits of the middle Coastal Plain, are: the Brandywine, Coharie, and Sunderland Formations of Stephenson (1912) and Cooke and others (1943) and morphostratigraphic units (msu) of Daniels and others (1972). They disconformably overlie Cretaceous to Miocene units and are variable lin thickness and composition and are unfossiliferous. In general, they consist of lower coarse sand and gravel which grade upward 1nto clay, silt, and fine sand in any combination. Kaolinite is the dominant clay-size constituent. The sediments of the middle Coastal Plain display cross-bedding and channeling in the lower part and represent a fluvial origin. They are considered Pliocene to early Pleistocene age.

The lower Coastal Plain occurs east of the Surry scarp. It is a stepped sequence of seaward sloping terrace plains similar to the middle Coastal Plain. The Walterboro $(1.4 \mathrm{~m})$ and Suffolk $(6 \mathrm{~m})$ scarps separate the seaward sloping terrace plains into three units: the Wicomfco msu, the Talbot msu, and the Suffolk msu. Sediments in the lower Coastal Plain are principally marine and show the effects of a depositional topography. Sediments underlying these terrace plains are variable in type and thickness and are considered mid to late Pleistucene.

\section{STRUCTURAL GEOLOGY}

The Cape Fear arch in southern North Carolina is the principal structural feature of the Atlantic Coastal Plain Province. It has been rcfcrred to as a southeast plunging basement high extending from the fall line along the Cape Fear River to about Cape Fear. Harris and others (1979a) suggest that the Cape Fear arch is a northwest-trending basement fault that has experienced perlodic differential movement since the early Late Cretaceous and may have moved as recently as 75,000 years ago.

Harris and others (1979a) also suggest the presence of a fault, parallel to the Cape Fear fault, that coincides with Whiteoak River (Onslow-Carteret County line). This fault was also active during the early Late Cretaceous and periodically has experienced movement as recently as the Pleistocene. In addition, a northeast-trending fault 
parallel to the coast has been suggested as passing through Cove City, Craven County. This basement rooted feature has been called the "Carolina fault". No other structures are known in the Beaufort quadrangle.

MINERAL RESOURCES

There are no reported occurrences of uranium, niobium, $t$ in, beryllium, lithium, tungsten, vanadium, thorium, zircon, or rare earth minerals in the quadrangle. In addition, there are no igneous intrusions of pegmatites or massive sulfides in the area. There are commercial deposits of nonmetallic mineral resources, including sand and gravel and limestone currently being mined.

\section{Limestone}

Major commercial operations mine limestone at Castle Hayne in New Hanover County and at Belgrade in Onslow County. Minor operations for limestone occur at Maple Hill, Pender County, and at Silverdale in Onslow County.

\section{Sand and Grave1}

Sand and gravel are locally mined throughout the quadrangle.

\section{Others}

Although no other commercial operations are active in the quadrangle, the widespread occurrence of glauconite and phosphate in Coastal Plain sediments and the potential associations of uranium or thorium or both with these minerals necessitates their discussion.

Glauconite occurs in concentrations of up to $30 \%$ in some zones of the Peedee Formation, Beaufort Formation, and Castle Hayne Limestone. In addition, glauconite mixed with phosphate coats many disconformities. Because Yasyrev (1966) demonstrated that glauconites average $400 \mathrm{ppm}$ thorium and $10 \mathrm{ppm}$ uranium, proper conditions of diagenesis may result in enrichment of uranium or thorium in associated sediments.

Scattered concentrations of phosphate occur in the Peedee Formation, the Beaufort Formation, the Castle Hayne Limestone, and the Pungo River Formation. Because of sufficient concentration in the Pungo River Formation, they are mined by Texas Gulf Sulphur at Aurora in Beaufort County (Rocky Mount quadrangle). Uranium is produced as a byproduct of phosphate mining in Florida, so there is the potential for commercial accumulation of uranlum and thorium in North Carolina Coastal Plain. However, no concentrated zones of phosphatic minerals have been noted in the Beaufort quadrangle.

The generalized geology of the quadrangle is shown in Plate 2. 
GEOLOGIC LITERATURE FOR THE BEAUFORT QUADRANGLE

$\underline{\text { Previous Studies }}$

Detailed geologic mapping in the Beaufort quadrangle is sparse (Figure 2); only Mixon and Pilkey (1976) have mapped in detall the surface distribution of the sediments, but their study was confined to the area east of $77^{\circ} \mathrm{W}$ longitude. Fallaw (1963) mapped the distribution of rocks in the Rocky Point quadrangle and the adjacent coastal area.

Regional geologic mapping of the North Carolina Coastal Plain was completed by Stephenson (1923) for the Cretaceous and by Clark and others (1912) for the Tertiary. Brown and others (1972) reported on the subsurface distribution of Cretaceous and Tertiary sediments trom New York to North Carolina. Baum and others (1978a) and Ward and others (1978) revised the stratigraphy of the Eocene to Miocene of the North Carolina Coastal Plain. The generalized areal distribution of the Tertiary section was shown by Baum and others (1978a). These reports represent the only major studies that attempt to delineate the surface and subsurface distribution of sediments and rocks in the quadrangle.

Recent concentrated studies on specific units have been made on the Peedee Formation by Brett (1961), Swift (1964), and Curran (1968); the Rocky Point Member by Cunliffe (1968) and Harris (1978b); the Beaufort Formation by Carlson (1976), Harris and Baum (1977), and Brown and others (1977); the Castle Hayne Limestone by Upchurch (1973) and Baum (1977); the Trent Formation by Baum (1977); and Belgrade and Silverdale formations by Baum and others (1978a). The Pungo River Formation has been studied by Miller (1971) and Holland (1974); the Yorktown-Duplin Formations by Howard (1966), Blackwelder (1971) and Blackwelder and Ward (1979); the Waccamaw and James City Formations by Howard (1966), DuBar and Solliday (1963), Woodas (1965), DuBar and othero (1974a), Campbell and others (1975), and Zullo and Harris (1978); and the Canepatch and Flanner Beach Formations by DuBar and Solliday (1963) and DuBar and others (1974b).

Current Research

The Geology and M1neral Resources Section (GMRS) of the North Carolina Department of Natural and Economic Resources has initiated a program to produce reconnaissance geologic maps tor the entire state. 'l'he state hás been divided into 17 multi-county planning regions that the maps will cover. The GMRS plans to have open-file reports on the Coastal Plain by 1981. Mapping in the Coastal Flain has not been started.

Two graduate students at the University of North Carolina at Chapel Hill are currently working on doctoral dissertations that relate to the geology of the Beaufort quadrangle: Lee. Otte (under the direction of Danlel A. Textris) is studying the Castle Hayne LImestone in Duplin County; Edward Custer (under the direction of Roy L. Ingram) is examining the subsurface distribution and depositional environments of the Cretaceous formations in the Cape Fear arch region. In addition, Roy L. Ingram, the University of North Carolina at Chapel Hill, is under contract from the North Carolina Energy Institute to assess the peat resources of North 
Carolina. His group has actively been examining peat deposits in the Beaufort quadrangle.

Lauck Ward and Blake Blackwelder of the U.S. Geological Survey have been studying the Tertiary units in the quadrangle.

Thomas Worsley and two graduate students (Joe Finneran and D. Sekel) at Ohio University are examining nannofossils in the Peedee Formation and the Tertiary units of North Carolina. Kevin Turco has recently completed a master's thesis at Ohio University on Tertiary nannofossils in the North Carolina Coastal Plain.

Philip M. Brown of the U.S. Geological Survey, Raleigh, North Carolina, and W. Burleigh Harris, University of North Carolina at Wilmington, have recently taken seven shallow cores from locations in Brunswick, New Hanover, and Pender Counties and are studying the Upper Cretaceous and Tertiary sections. In addition, Victor Zullo and W. Burleigh Harris, University of North Carolina at Wilmington, are examining the Tertiary and Quaternary stratigraphy and paleontology of the North Carolina Coastal Plain.

\section{GEOLOGIC HISTORY}

The Coastal Plain Physiographic Province extends along the Atlantic Coast from southern Florida to the Grand Banks of Newfoundland. The sediments and sedimentary rocks generally form a wedge-shaped mass that thickens from a featheredge along the fall line to a maximum along the coastal margin. However, the recent recognition that a basement rooted tectonic framework has affected Coastal Plain deposition suggests that local variations in sediment thickness and lithology occur. Coastal Plain sediments and rocks rest unconformably on a Paleozoic and Precambrian basement of igneous and metamorphic rock or early Mesozoic sedimentary rock. Upper Cretaceous through Holocene sediments and sedimentary rocks occur in the Beaufort quadrangle.

During early Late Cretaceous time, a transgression of the ocean on to the Piedmont surface estabilished a time-transgressive stratigraphic sequence: the Cape Fear and Middendorf Formations - fluvial, fluviomarine; the Black Creek Formation - estaurine, lagoonal, and 1ittoral; and the Peedee Formation - open marine shelf. Although local disconformities exist between the Cape Fear and Middendorf, and the Black Creek and Peedee Formations, formational boundaries are genera11y of an intertonguing nature and suggest the absence of major eustatic changes in sea level or tectonism.

During latest Cretaceous, uplift of the Cape Fear arch established a nearshore regressive sequence in the dominantly transgressive regime of the Peedee Formation. This started deposition of the shallow marine Rocky Point Member of the Peedee Formation north of and along the Cape Fear arch. The close of the Mesozoic is marked by regression of the sea and probably uplift of the Cape Fear arch. The arch appears to have remained high during the entirety of Paleocene deposition, as Paleocene sediments arc restricted to the area north of the arch axis. 
The Castle Hayne Limestone represents a major transgression of the sea over Cretaceous and Paleocene sediments and rocks. The Castle Hayne was deposited during a temporal transgression during the middle and late Eocene. In New Hanover County, the presence of dolomitized sediments in the Castle Hayne, which are thought to have originated through dorag dolomitization, suggest that the Cape Fear arch was active and a positive element. Subsequently, during late Eocene, the Castle Hayne sea transgressed across the arch and deposited late Eocene sediments. As the sea withdrew from the Coastal Plain after Castle Hayne deposition, the Cape Fear arch emerged, and uplift and erosion of the area south of the Neuse fault resulted in deposition of the New Bern Formation north of the Neuse fault as a regressive (?) pulse during latest Eocene.

During the 0ligocene, the sea transgressed the entire area north of the Cape Fear arch and deposited the shallow marine Trent formation. 'Ihe Trent Formation displays lithofacies indicative of transgression and regression. The extensive eustatic sea level drop in the mid-oligocene suggest that Trent deposition occurred during the early to middle Oligocene.

The Belgrade and Silverdale Formations were deposited during the early Miocene as the sea transgressed the area from the east. The coastal area was not tectonically active during the early Miocene.

During the middle Miocene, the sea transgressed from the east and deposited the Pungo River Formation in the area north of the Neuse fault. This restriction of the Pungo River Formation suggests that the Neuse fault was active during the middle Miocene. The seas retreated from the Coastal Plain during the late Miocene.

A major transgression occurred during the late Miocene (?) or early Pliocene when the Yorktown and Duplin Formations were deposited seaward of the Coats (Orangeburg) scarp. The Yorktown-Duplin transgression resulted in deposition of strata on a late Cretaceous to Paleocene dissected surface. Regression of this early Plfocene sea may have been the direct result of polar ice cap advance (DuBar and others 1974a) or tectonism (Zullo and Harris, 1979). The present distribution of the Yorktown and Duplin Formations suggest elevation of the area between the Cape Fear and Neuse Faults after regression of the sea.

During the Pleistocene, the Waccamaw-James City rose to a maximum level of about $30 \mathrm{~m}$, occupying the Surry scarp. Therefore, Waccamaw and James City sediments are restricted to the area south of the Cape Fear River, to a narrow zone along the coast east of the Hanover scarp, and (in the north) east of the Surry scarp. Withdrawal of the WaccamawJames City seas from the Coastal Plain was followed by the less extensive Canepatch-Flanner Beach transgression that occupied part of the unelevated outer Coastal Plain and reoccupied the Hanover scarp. This transgression occurred during the late Pleistocene. Undifferentiated late Pleistocene sediments were deposited east of the Suffolk and Boque scarps during the latest high stand of sea level. 
GFOT.OGY AND MTNFRAT, RFSOUIRCES OF THE.

ROCKY MOUNT

$1^{\circ} \times 2^{\circ}$ NTMS QUADRANGLE 
THIS PAGE

\section{WAS INTENTIONALLY \\ LEFT BLANK}

42 
Location and Physical Geography 44

Stratigraphy 44

Piedmont 44

Coastal Plain 45

Structura1 Geology 52

Mineral Resources 52

Géologic Literature For The Rocky Mount Quadrangle 53

Geologic History 54 


\section{LOCATION AND PHYSICAL GEOGRAPHY}

The Rocky Mount quadrangle covers about 20,000 sq $\mathrm{km}$ in North Carolina in the Atlantic Coastal Plain Province; however, Piedmont rocks of the Eastern Slate Belt are present in the extreme northwest part. Elevations range from greater than $65 \mathrm{~m}$ in the extreme northwest to sea level in the eastern part of the quadrangle. Temperatures are moderate, with the normal $25.7^{\circ} \mathrm{C}$ in July and $5.8^{\circ} \mathrm{C}$ in January. Dense vegetation, low relief, the existence of a thin veneer of surficial sand, and a deeply weathered soil profile make geologic mapping difficult.

The Atlantic Coastal Plain is physiographically divisible into two distinct parts in the Rocky Mount quadrangle. The middle Coasta1 P1ain extends from the Coasts scarp (Orangeburg) at an approximate altitude of $33 \mathrm{~m}$. The lower Coastal Plain extends from the Surry scarp to the coastal margin. The middle and lower Coastal Plains are characterized by differences between primary depositional features and subsequent erosional features.

A well-integrated system of creeks and rivers drains the quadrangle. The major rivers are the Neuse, Tar, and Roanoke, which head in the Piedmont. The Northeast Cape Fear, Trent, Pungo, and Alligator rivers head in the Coastal Plain and are minor drainage systems. The quadrangle is gently rolling to flat with steepest topography usually adjacent to major drainage systems.

S'I'RA'I' IGRAPHY

PI F.IJM(IN']'

\section{Eastern Slate Belt Rocks}

Edstern Slate Beli Rucks uccur in the extreme northwest part of the quadrangle. They consist of a sequence of low rank metavolcanicsedimentary rocks that may reach a thickness of over $600 \mathrm{~m}$. These 10 w rank rocks include mainly sericite-chlorite phyllite, slate, argillite, metagraywacke, quartzite, greenstone, and comparable metafelsites (Parker, 1968) and are regionally in the greenschist facies of metamorphisin.

\section{Granile Plutons}

Granitic plutons are exposed west of Rocky Mount and northwest and southwest of Wilson along the larger streams. The plutons are variable in crystal size and biotite content. Coarse-grained red microcline granite with little plagioclase and biotite is the common type. 
COASTAL PLAIN

Middendorf Formation

The name Middendorf was first applied by Sloan (1904) in South Carolina for sand and kaolinitic clay. Although abandoned in favor of the term Tuscaloosa (Cooke, 1936), Swift and Heron (1969) formally proposed that the Middendorf Formation be recognized for beds between the "Hamburg" (Cape Fear Formation) and the overlying Black Creek Formation. The railroad cut on the Seaboard Railroad $3.2 \mathrm{~km}$ east of Middendorf (Chesterfield County, S.C.) is generally accepted as the type section. The Middendorf disconformably overlies the Cape Fear Formation, Triassic basin sediments, and crystalline rocks of the Piedmont.

The Middendorf Formation is a fluvial unit that crops out principally in the upper Coastal Plain above the Coasts (Orangeburg) scarp south of Fayetteville, N.C. However, limited exposures are present in the area of Goldsboro and along the Roanoke and Tar Rivers. It is composed of argillaceous and micaceous sand with lenses of white to gray mudstone and discontinuous conglomerate. Cross-bedded quartz wacke with basal conglomerate is the main sediment type with kaolinite the dominant matrix component (Heron and Wheeler, 1964). Fossil leaves, clay pebbles, channeling, local disconformities, point bar and channel fill deposits suggest the unit is fluvial in origin (Heron, 1958). The Middendorf Formation, which probably does not exceed $70 \mathrm{~m}$ in thickness (Swift and Heron, 1969), contains a well known and abundant flora (Berry, 1914; Dorf, 1952) and is considered Coniacian and Santonian in age.

\section{Black Creek Formation}

The Black Creek Formation is transitional between the fluvial Middendorf Formation and the marine Peedee Formation. It was named by Sloan (1907) for exposures along Black Creek, Florence and Darlington Counties, S.C. In the Rocky Mount quadrangle, the Black Creek Formation crops out south of the Pamlico and Tar Rivers west of Kinston, N. C.

The Black Creek Formation is characterized by laminated dark gray clay intercalated with gray to yellow-orange sand that is often crossbedded. Claystone forms the bulk of the formation (Heron and Wheeler, 1964). Also abundant lignitized wood and less abundant sulfide aggregates are present. Black Creek sediments represent deposition in estuarine, lagoonal and Littoral environments (Benson, 1968). The formation has an estimated average thickness of $100 \mathrm{~m}$ but may reach greater than $200 \mathrm{~m}$ near the coast in the subsurface (Benson, 1968).

The Black Creek Formation contains a flora of Austin and Taylor age (Dorf, 1952) that is essentially synchronous with plant mega-fossils from the Middendorf Formation (Berry, 1914; Dorf, 1952). Wo1fe (1976)

assigned the upper part of the Black Creek Formation to his CA-3 to CA-5 palynormorph assemblage zones which range from lower to upper Campanian (Taylor). 
The Peedee Formation was named by Ruffin in 1843; Sloan (1908) $). .$. designated the type locality as Burches Ferry, $16 \mathrm{~km}$ south of the U.S. Route 301 bridge over the Pee Dee River, Florence County,-S.C: The Peedee Formation crops out south of the Pamlico and Tar Rivers in a broad outcrop belt with Kinston in the center.

The Peedee Formation is a neritic, dark micaceous, argillàceous sand characterized by an abundant molluscan fauna (Stephenson, 1923). Near the base, the mollusks are concentrated and form a distinctive lithic unit that was designated the "Snow Hill Member" and placed in the Black Creek Formation by Stephenson (1923). However, Brett and Wheeler (1961) proposed the abandonment of the name and assigned the beds to the basal Peedee. The Peedee Formation has a thickness ranging from a feather edge in the west to a maximum of greater than $100 \mathrm{~m}$ in the subsurface of eastern Pamlico County (Brown and others, 1972).

Swift (1964) concluded that the Peedee Formation was deposited on an open shelf and divided the Peedee into two depositional units: an inner shelf suite composed of sand and muddy sand, representing the lower Peedee, and an outer shelf suite composed principally of calcareous muddy sand and sandy mud, representing the upper Peedee.

The Peedee Formation is Campanian and Maestrichtian; the upper part has been dated with Rb-Sr glauconite ages at $68.1 \mathrm{~m} . \mathrm{y}$. (Harris, 1976).

Beaufort Formation

Brown (1959) named the Beaufort Formation from a well drilled at Chocowinity (Beaufort County), N.C.; subsequently, the unit was recognized in outcrop in the area around Kinston, principally along Moseley Creek and the Neuse River.

The Beaufort Formation consists of two members: the lower Jericho Run Member consists of mudstone with intercalations of chert and sandstone; the upper unnamed member consists of unconsilidated, sandy, foraminiferal glauconitic sediments alternating with thinner, slightly glauconitic, foraminiferal biomicrosparites. The unit probably does not exceed $5 \mathrm{~m}$ in surface exposures; however, it attains a thickness of approximately $46 \mathrm{~m}$ in the subsurface of eastern Carteret County (Brown and others, 1972).

The siliceous mudstone and basal phosphate-pebble conglomerate of the lower Beaufort were deposited in the inner neritic environment (Carlson, 1976). The unnamed sediments were deposited in a normal marine environment that ranged from inner to middle neritic.

Based on planktic foraminifera, the siliceous mudstone is early Danian in age and belongs to Berggrens' (1972) P1 zone. Planktic foraminifera from the upper unconsolidated glauconitic sediments are Thanetian and belong to Berggrens' (1972) P4 zone. Rubidium-strontium glauconite ages of $55.7 \mathrm{~m} . \mathrm{y}$. and $57.8 \mathrm{~m} . \mathrm{y}$. from the P4 zone suggest a Thanetian age for the unnamed member (Harris and Baum, 1977). 
The Castle Hayne Limestone was named by Miller (1912) for "exposures in the vicinity of the town of Castle Hayne." The type section was concurrently designated the Martin-Marietta quarry, 4.5 northeast of Castle Hayne, by Baum and others (1978a), and the Ideal Cement Co. quarry, $6 \mathrm{~km}$ northeast of Castle Hayne, by Ward and others (1978). The Castle Hayne Limestone forms a continuous outcrop belt. south of the Pamlico River between Kinston and New Bern. It also occurs as scattered outliers west of the outcrop belt in Jones, Lenoir, Wayne, Pitt, and Greene counties.

The Castle Hayne Limestone consists of three lithofacies (Baum and others, 1978a): lower phosphate pebble conglomerate, middle bryozoan biosparrudite, and upper bryozoan biomicrudite. Dolomitization occurs in some parts of the unit (Baum and others, 1978a). The unit has a maximum outcrop thickness of about $5 \mathrm{~m}$ and subsurface thickness of about $250 \mathrm{~m}$ in eastern Carteret County.

The abundance of stenohaline fauna in the Castle Hayne Limestone is indicative of a warm temperate to tropical marine environment. Based on the assemblages of bryozoans, mollusks, crinoids, and other less abundant faunal elements, Baum (1977) suggested that the bryozoan biomicrudite was deposited in waters $30-50 \mathrm{~m}$ deep and the bryozoan biosparrudite in waters less than $30 \mathrm{~m}$ deep.

The Castle Hayne Limestone is considered by Brown and others (1972), Baum and others (1978a), and Baum and others (1979a) as Claibornian (middle Eocene); however, Canu and Bassler (1920), Kellum (1925), Cooke (1959) and Harris and others (1979b) consider the unit Jacksonian (late Eocene). Harris and others (1979b) determined a $34.8 \pm 1 \mathrm{~m} \cdot \mathrm{y} \cdot \mathrm{Rb}-\mathrm{Sr}$ isochron age on glauconites for the bryozoan biomicrudite facies: The Castle Hayne Limestone probably represents deposition during the Claibornian and Jacksonian.

\section{New Bern Formation}

The New Bern Formation is a sandy, pelecypod-mold biomicrosparrudite that disconformably overlies the Castle Hayne Limestone. The unit was first named by Baum and others (1978a) for exposures at the Martin-Marietta quarry located at New Bern. The formation crops out only in the southern part of the Rocky Mount quadrangle in Jones County and along the Neuse River. At the type section, the New Bern Formation is about $9 \mathrm{~m}$ thick and consists of lower calcareous quartz arenite and sandy, fine pelecypod-mold biomicrosparrudite.

The New Bern Formation was deposited in a transgressive depositional system ranging from intertidal in the lower part through a sandy, continental shelf at depths of $7-40 \mathrm{~m}$ in the upper part. The fauna suggest a warm temperate marine environment. Because of the lack of diagnostic fossils in the New Bern. Formation, and because the formation is disconformably overlain by the oligocene Trent Formation, the New. Bern is assigned a latest Jacksonian age. 
$\underline{\text { Trent Formation }}$

The type section of the Trent Formation was designated the Trent River from New Bern to Trenton by Miller (1912); however, because the section contains two distinct formations, Baum and others (1978a) restricted the Trent Formation to the outcrops occurring along the river from New Bern to within $0.7 \mathrm{~km}$ of Pollocksville (Jones County). Ward and others (1978) named these same exposures the River Bend Formation. The Trent Formation disconformably overlies the New Bern Formation and crops out in a narrow belt along the Trent and Neuse Rivers in Jones and Craven Counties.

Three lithofacies characterize the Trent Formation: lower sandy, echinoid biosparite; sandy pelecypod-mold biomicrudite; and harnacle, pelecypod-mold biosparrudite. The formation has all approximate thickness of 9-10 $\mathrm{m}$ along the Trent River, Craven County.

The Trent Formation represents a transgressive-regressive sequence that was deposited in a warm temperate marine environment. The basal part was deposited in the intertidal zone, the middle on a sandy, continental shelf at depths of $7-40 \mathrm{~m}$, and the upper part in a shallow marine regressive sea. Because of the concurrence of 01igocene to Recent mollusks and Eocene to Oligocene barnacles, the Trent Formation is considered 01igocene age (Baum and others, 1978a).

\section{Belgrade and Silverdale Formations}

The basal $7.5 \mathrm{~m}$ of the Martin-Marietta quarry located south of the White Oak River in the town of Belgrade, Onslow County, was designated the type section of the Belgrade Formation by Baum and others (1978a). Ward and others (1978) regard this section the upper part of their River Bend Formation (Uligocene). The Belgrade Formation consists of lower unconsolidated quartz arenite that grades upward into sandy, pelecypod-mold biomiçudite.

The quarry located just east of the city of Silverdale, Onslow County, was designated the type section of the Silverdale Formation. It consists of a basal dense, sandy, pelecypod-mold biomicrudite that gradcs upward into an unconsolidated, sandy, pelecypod hiomicrudite. Discontinuous channel sands containing Crassostrea gigantissima and an abundant molluscan fauna that grade upward into clay in Jones and Craven Counties are considered part of the Silverdale Formation.

The Belgrade and Silverdale Formations disconformably overlie the Trent Formation and occur only in Jones County. Exposures are restricted to river and stream banks and open pits. Faunal constituents of the two formations suggest deposition on a sandy, continental shelf in 1agonna1, brackish water environments.

The Silverdale Formation has a well documented Miocene fauna (Kellum, 1925; 1926; Richards, 1948; Vokes, 1967; 1970): Because of barnacles found in the Belgrade Formation, the two units are considered equivalent in age. Therefore, the Belgrade and Silverdale Formations are considered Miocene age (Baum and others, 1978a). 


\section{Pungo River Formation}

Although the Pungo River Formation does not crop out in the Rocky Mount quadrangle, it occurs in the subsurface and is mined for its phosphate. Kimrey (1964) proposed the name Pungo River Formation for middle Miocene phosphatic sediments described by Brown (1958) from the subsurface of Beaufort County. A core hole located at $76^{\circ} 34^{\prime} 59^{\prime \prime} \mathrm{W}$, $35^{\circ} 35^{\prime} 58^{\prime \prime} \mathrm{N}$, Beaufort County, was chosen as the type section.

The chief lithologies of the Pungo River Formation are light-green diatomaceous clay and fine to medium grained quartz sand containing varying amount of greenish-brown clay and light to dark brown collophane. Light olive-green dolomite and dolomitic limestone, white to light gray molluscan limestone, calcareous clay, shell hash, and chalk are less abundant constituents. The unit reaches a maximum thickness of about $45 \mathrm{~m}$ in the subsurface of eastern Carteret County.

The Pungo River Formation was deposited in an open marine, normal salinity, shallow shelf environment with water temperatures cool to cool-temperate. Gibson (1967) concluded that most of the unit was deposited in water $100-200 \mathrm{~m}$ deep.

The Pungo River Formation is considered correlative with the middle Miocene Calvert Formation of Maryland on the basis of benthic foraminifera (Brown, 1958; Gibson, 1967). Glbson (1967) also concluded from mollusks that the formation was middle Miocene.

\section{Yorktown Formation}

The Yorktown Formation was named by Clark and Miller (1906) for exposures of fossiliferous sand and clay on the York River at Yorktown, virginia. It is characterized by an abundant and varied fauna and has been divided into four members in the Virginia Coastal Plain by Blackwelder and Ward (1976). These members have not been traced and mapped in northeastern North Carolina. Therefore, on the geologic map, all members are grouped as the Yorktown Formation.

The Yorktown Formation represents one of the most extensive transgressions in the Rocky Mount quadrangle. Consequently, the unit occurs as a continuous covering over most of the western half of the quadrangle. In addition, it occurs as outliers on pre-Miocene units (Piedmont to Coastal Plain). The lithology of the formation ranges from gray to blue shell marl, molluscan limestone, fine to coarse sand, and massive clay with interbedded micaceous sand. The thickness of the Yorktown Formation in outcrop probably does not exceed $6 \mathrm{~m}$; in the subsurface it reaches a thickness of greater than $120 \mathrm{~m}$ just north of Lake Mattamuskeet (Hyde County).

The Yorktown Formation represents deposition in a warm temperate climatic zone. Specific environments are: shallow marine shelf; open bay, sound, or lagoon; and low salinity bay or estuary. The depth of deposition was probably less than $30 \mathrm{~m}$ (Bailey, 1970). 
Traditionally, the Yorktown Formation has been considered late Miocene (Cooke, 1936; Richards, 1950; and Copeland, 1964). However, recent work by DuBar and others (1974a), Baum and Wheeler (1977), and Blackwelder and Ward (1979) suggests the formation is Pliocene.

James City Formation

The James City Formation was described by DuBar and Solliday (1936) from strata exposed along the banks of the Neuse River estuary near the town of James City, Craven County, N.C. It includes part of the Croatan Formation of previous workers and the Small sequence of Danie1s and others (1972). The fauna of the James City Formation is correlated with that of the Waccamaw Formation; therefore, the two units are considered equivalent. The James City Formation only occurs disconformably on top of the Yorktown Formation, along the Neuse River south of New Bern (Craven County).

The James City Formation consists of slightly to moderately indurated, very fine quartz sand, silt, and clay. An abundant, well preserved molluscan fauna is usually present; however, in places all carbonate has dissolved and fossil molds are present. The maximum thickness of the unit probably does not exceed $15 \mathrm{~m}$, although in outcrop no more than $3 \mathrm{~m}$ are present.

Molluscan assemblages from the unit suggest its deposition in a semirestricted environment such as an embayment similar to modern Pamlico Sound. Water depth during deposition probably did not exceed 7-8 m (DuBar and others, 1974b). Recent workers suggest that the James City Formation is early Pleistocene in age, based on its correlation with the Waccamaw Formation to the south.

Flanner Beach Formation

The Flanner Beach Formation was first described by DuBar and Sn11.iday (1963) along the Neuse River at Flanner Beach, Craven County, N. C. Here it includes the Newport sand, Arapahoe sand, Minnesott sand, and Beard Creek member of Mixon and Pilkey (1976). The Flanner Beach Formation covers most of the eastern part of the Rocky Mount quadrangle.

The Flanner Beach Formation consists of some silt and clay and slightly indurated, very fine to fine sand with minor medium to coarse sand. The upper part of the unit is characterized by cross-stratification. Calclum carbonate comprises 20 percent or more of some lithologies. and is mainly in the form of mollusks. The unit has a maximum thickness of about $10 \mathrm{~m}$.

Sediments mapped as the Flanner Beach Formation represent deposition in a barrier-island, lagoonal complex; therefore, fauna and sediments represent brackish to normal marine waters. The Flanner Beach Formation is considered medial Pleistocene and equivalent to the Canepatch. Formation of the southern part of North Carolina. 
Undifferentiated Late Pleistocene and Holocene Sediments

Undifferentiated late Pleistocene sediments include the Core Creek sand, the Atlantic sand, Cedar Island sand, North Bay sand, Bogue sand, and Beaufort sand of Mixon and Pilkey (1976). Also included in this category is the "Cherry Point unit" of DuBar and others (1974b), which is restricted to the area of the Neuse River.

These sediments occur east of the Suffolk or Bogue scarps. They consist dominantly of silty and clayey fossiliferous sand, very pale gray to light greenish-gray, fine to medium nonfossiliferous quartz sand, and associated silty and clayey sands which vary in thickness.

Holocene sediments include beach and dune sand and fossiliferous sand and soft silty and clayey mud and peat that occur along the barrier islands and the sounds. They are not differentiated from late Pleistocene sediments.

\section{Surf1c1al Deposits}

The middle and lower Coastal Plain in the Rocky Mount quadrangle is. covered by a thin veneer of gravel, sand, silt, and clay that almost everywhere conceals the older formations. The middle Coastal Plain includes the area between the Coats (Orangeburg) scarp and the Surry scarp, and consists of three seaward sloping terrace plains separated by the Wilson Mills scarp $(65.5 \mathrm{~m})$ and the Kenly scarp $(45 \mathrm{~m})$. These three plains, which form the bulk of the surficial deposits of the middle Coastal Plain, are: the Brandywine, Coharie, and Sunderland formations of Stephenson (1912) and Cooke and others (1943) and morphostratigraphic units (msu) of Daniels and others (1972). They disconformably overlie Piedmont crystalline rocks and Cretaceous to Miocene units of the Coastai Plain. They are variable in thickness and composition and are unfossiliferous. In general, they consist of lower coarse sand and gravel which grade upward into clay, silt, and fine sand in any combination. Kaolinite is the dominant clay-size constituent. The sediments of the middle Coastal Plain display cross-bedding and channeling in the lower part and represent a fluvial origin. They are considered. Pliocene to early Pleistocene age.

The lower Coastal Plain occurs east of the Surry scarp. It is a stepped sequence of seaward sloping terrace plains similar to the middle Coastal Plain. The Waltersboro $(14 \mathrm{~m})$ and Suffolk $(6 \mathrm{~m})$ scarps separate the seaward sloping terrace plains into the Pamlico Formation of Clark and others (1912) or the Wicomico msu, the Talbot msu, and the Suffolk msu of Daniels and others (1972). Sediments in the lower Coastal Plain are principally marine and show the effects of a depositional topography. Sediments underlying these terrace plains are variable in type and thickness and are considered mid to late Pleistocene. 
Coastal Plain strata in the Rocky Mount quadrangle occur as a seaward-thickening and dipping monoclinal wedge. This uniform dip to the east at a rate of $6-10 \mathrm{~m} / \mathrm{km}$ is disrupted only in the area of Kinston (Leonir County) where the Graingers Wrench zone affects the overlying Cretaceous, Paleocene, and Eocene strata and by the Neuse fault along the Neuse River.

The Graingers Wrench zone is a northeast trending structural mosaic of horsts, "grabens, and half grabens. These en echelon faults overlie a buried Triassic basin and have experienced Paleocene and post-Paleocene movements (Harris and others, 1979a). The Neuse fault trends northwest-southeast from about Smithfield, Johnston County, to Bogue Inlet, the Unslow-Carteret County line. The tault is probably part of a series of basement faults that occur between the Neuse and New Rivers. Movement along the Neuse fault has occurred periodically from Lower Cretaceous through the Quaternary.

Harris and others (1979a) have also suggested the presence of a basement rooted northeast-trending fault (Carolina fault), parallel to the Graingers Wrench zone and passing through Cove City, Craven County. Times of movement of the Carolina fault have not been determined. No other structures occur in the quadrangle.

\section{MINERAL RESOURCES}

There are no reported occurrences of uranium, niobium, tin, beryllium, lithium, tungsten, vanadium, thorium, zircon, or rare earth minerals in the quadrangle. In addition, there are no reported igneous intrusions of pegmatites or massive sulfides in the area. There are commercial deposits of non-metallic mineral resources, including sand, gravel, stone, and phosphate currently being mined in the area. These locations are shown on the geologic map.

Sand, Grave1, and Crushed Stone

Major commercial operations mine sand, gravel, and stone throughout the quadrangle. Stone for crushing is mined at New Bern (Craven County), at Fountain (Pitt County), Eim City (Wilson County), and Rocky Mount (Edgecomb County). In addition, there are minor operations at Kinston (Lenoir County), and Windsor (Bertie County).

\section{Phosphate}

A major accumulation of phosphate underlies seven or eight counties, including Beaufort County, in the Aurora Area. This deposit, which may be one of the largest in the world, yields about 2-3 miliion tons of phosphate per year for Texasgulf, Inc. The phosphate occurs in the middle Miocene Pungo River Formation. Uranium is currently produced in Florida as a byproduct of phosphate production, and because phosphate at the Texasgulf, Inc. quarry may contain up to $50 \mathrm{ppm}$ uranium, a major source of uranium is present in the Coastal Plain part of the Rocky Mount quadrangle. 


\section{Others}

Although no other commercial operations are active in the quadrangle, the widespread occurrence of glauconite and phosphate in Coastal Plain sediments and the potential associations of uranium or thorium or both with these minerals necessitates their discussion.

Glauconite occurs in concentrations of up to $30 \%$ in some zones of the Peedee Formation, Beaufort Formation, and Castle Hayne Limestone. In addition, glauconite mixed with phosphate coats many disconformities. Because Yasyrev (1966) demonstrated that glauconites average $400 \mathrm{ppm}$ thorium and 10 ppm uranium, proper conditions of diagenessis may result in enrichment of uranium or thorium in associated sediments.

In addition to the major occurrence of phosphate in the Pungo River Formation, scattered concentrations of phosphate occur in the Peedee Formation, the Beaufort Formation, and the Castle Hayne Limestone. However, no concentrated zones of phosphate minerals have been noted in the quadrangle.

The generalized geology of the quadrangle is shown in Plate 3. GEOLOGIC LITERATURE FOR THE ROCKY MOUNT QUADRANGLE

Previous Studies

Detailed geologic mapping in the Rocky Mount quadrangle is sparse (Figure 3). Mixon and Pilkey (1976) have mapped in detail parts of the quadrangle; however, their work is confined to the lower 2.5 minutes east of $77^{\circ} \mathrm{W}$ longitude. Parker (1968) mapped the area north of $35^{\circ} 15^{\prime} \mathrm{N}$ latitude and west of $77^{\circ} 30^{\prime} \mathrm{W}$ longitude.

Regional geologic mapping of the North Carolina Coastal Plain was completed by Stephenson (1923) for the Cretaceous and by Clark and others (1912) for the Tertiary. Brown and others (1972) reported on the subsurface distribution of Cretaceous and Tertiary sediments from New York to North Carolina. Baum and others (1978a) and Ward and others (1978) revised the stratigraphy for the Eocene to Miocene of the North Carolina Coastal Plain. Baum and others (1978a) showed the generalized areal distribution of the Tertiary units for the southern part of the quadrangle.

Groundwater studies of the general geology of the quadrangle include: LeGrand (1960) on the Wilmington area; Pusey (1960) on the Goldsboro area; Nelson (1964) on the Swanquarter area; Sumison (1970) on the Greenville area; and Mundorff (1946) on the Halifax area. These studies do not show in detail the surface distribution of units.

Concentrated studies on specific units have been made on the Middendorf Formation by Ibrahim (1973); the Black Creek Formation by Benson (1968); the Peedee Formation by Brett (1961) and Swift (1964); the Beaufort Formation by Carleon (1976), Harrie and Baum (1977), and 
Brown and others (1977); the Castle Hayne Limestone by Baum (1977); the New Bern Formation by Baum (1977) and Thayer and Textoris (1972, 1977); the Trent Formation by Baum (1977); and the Belgrade and Silverdale Formations by Baum and others (1978a). The Pungo River Formation has been studied by Gibson (1967), Miller (1971), and Holland (1974); the Yorktown Formation by Bailey (1970, 1973) and Blackwelder and Ward (1979); the James City Formation by DuBar and Solliday (1963), Daniels and others (1972, DuBar and others (1974b); and the Flanner Beach Formation by DuBar and Solliday (1963) and BuBar and others (197.4b). In addition, Fallaw and Wheeler (1969) examined marine fossiliferous Pleistocene deposits in southeastern North Carolina. The undifferentiated Late Pleistocene and Holocene sediments and surficial sediments have been studied by Mixon and Pilkey (1976) and have been synthesized by Daniels and others (1972).

Current Research

The Geology and Mineral Resources Section (GMRS) of the North Carolina Department of Natura1 and Economic Resources has initiated a program to produce reconnaissance geologic maps for the entire state. The state has been divided into 17 multi-county planning regions that will be covered by the maps. The GMRS plans to have open-file reports on the Coastal Plain by 1981. Mapping in the Coastal Plain has not yet been started.

Current work in the Rocky Mount quadrangle is in progress by Roy. L. . Ingram at the University of North Carolina at Chapel Hill (peat resources), Thomas Worsley at Ohio University (nannofossil biostratigraphy), Duncan Heron at Duke University (origin and evolution of Core Banks), Philip Brown of the U.S. Geological Survey in Raleigh (core holes in the New Bern area), and Stanley Riggs at East Carolina University (phosphate origin and occurrence and uranium resources).

\section{GEOLOGIC HI3TORY}

The Coastal Plain Physiographic Province extends along the Atlantic Coast from southern Florida to the Grand Banks of Newfoundland. The sediments and sedimentary rocks generally form a wedge-shaped mass that thickens from a featheredge along the fall line to a maximum along the coastal margin. However, the recent recognition that a basement-rooted tectonic framework has affected Coastal Plain deposition suggests that local variations in sediment thickness and lithology occur. Coastal Plain sediments and rocks rest unconformably on a Paleozoic and Precambrian basement of 1gneous and metamorphic rock or early Mesozoic ocdimcntary rock. Precambrian (?) to early Paleozoic Piedmont rocks and Upper Cretaceous through Holocene sediments and sedimentary rocks occur in the Rocky Mount quadrangle.

Durling early Upper Cretaceous time a transgression of the ocean onto the Piedmont surface established a time-transgressive stratigraphic sequence in the Rocky Mount quadrangle: Middendorf Formation - fluvial, fluviomarine; the Black Creek Formation - estuarine, lagoonal and littoral; and the Peedee Formation - open marine shelf. Although local 
disconformities occur between the units, formational boundaries are generally of an intertonguing nature and suggest the absence of major eustatic changes in sea level or tectonism during the Upper Cretaceous. The close of the Mesozoic is marked by regression of the sea as a result of eustatic sea level drop and uplift of the Cape Fear region to the south.

During the Paleocene, eustatic sea level rise coupled with movement along Graingers Wrench zone and Neuse fault(?) created a depositional basin for Danian and Thanetian sediments. Lithofacies distribution suggests that Graingers Wrench zone was active during Paleocene deposition. The end of the Paleocene is marked by a major regression and withdrawal of the sea from the Coastal Plain.

The Castle Hayne Limestone represents the next major transgression of the sea over Cretaceous and Paleocene sediments and rocks. The Castle Hayne was deposited during a temporal transgression during the middle to late Eocene. This transgression covered most of the North Carolina Coastal Plain. As the sea withdrew from the Coastal Plain after Castle Hayne deposition, uplift and erosion of the area south of the Neuse fault resulted in deposition of the New Bern Formation north of Neuse fault as a regressive (?) pulse during latest Eocene.

During the Oligocene, the sea transgressed the entire North Carolina Coastal Plain and deposited the shallow marine Trent Formation. The Trent Formation displays lithofacies indicative of transgression and regression. The extensive eustatic drop of sea level during the middle oligocene suggests that Trent deposition occurred during early to middle 01igocene.

The Belgrade and Silverdale Formations were deposited during the lower Miocene as the sea transgressed the area from the east. The coastal area was not tectonically active during the lower Miocene.

During the middle Miocene, the sea transgressed from the east and deposited the Pungo River Formation in the area north of the Neuse fault. This restriction of the Pungo River Formation suggests that Neuse fault was active during the middle Miocene. The seas retreated from the Coastal Plain during the late Miocene.

A major transgression occurred during the late Miocene(?) or early Pliocene when the Yorktown was deposited seaward of the Coats (Orangeburg) scarp. The Yorktown transgression resulted in deposition of strata on a dissected surface of Precambrian(?) to Paleocene strata. Regression of this early Pliocene sea may have been a direct result of polar ice cap advance (DuBar and others, 1974a) or tectonism (Zullo and Harris, 1979). The present distribution of the Yorktown Formation suggests that downdropping of the area north of the Neuse fault resulted in preservation of Yorktown sediments. 
During the Pleistocene, the James City sea rose to a maximum level of 20 to $30 \mathrm{~m}$, occupying the Hazleton or Surry scarp(?). Therefore, James City sediments are restricted to a narrow zone along the coast, southeast of Hanover scarp and east of Surry scarp(?). Withdrawal of the James City sea from the Coastal Plain was followed by the less extensive Flanners Beach transgression that occupied part of the unelevated outer Coastal Plain. Maximum submergence was about $15 \mathrm{~m}$. This transgression occurred during the late Pleistocene. Undifferentiated late Pleistocene sediments were deposited east of Suffolk and Bogue scarps during the latest high stand of sea level. 
1

GEOLOGY AND MINERAL RESOURCES OF THE

NORFOLK

$1^{\circ} \times 2^{\circ}$ NTMS QUADRANGLE 
58 
Location and Physical Geography 60

Stratigraphy 60

Piedmont 60

Coastal Plain 61

Structural Geology 66

Minera1 Resources 67

Geologic Literature for the Norfolk Quadrangle 67

Geologic History 68 
The Norfolk $1^{\circ} \times 2^{\circ}$ NTMS quadrangle covers about $20,000 \mathrm{sq} \mathrm{km}$ in the North Carolina and Virginia Atlantic Coastal Plain and Piedmont provinces. Elevations range from greater than $130 \mathrm{~m}$ in the western part (Piedmont) to sea level in the eastern part. Rainfall averages 114.07 $\mathrm{cm} /$ year in Norfolk, the largest city, and temperatures are moderate, with the normal $23.11^{\circ} \mathrm{C}$ in July and $2.39^{\circ} \mathrm{C}$ in January. Dense vegetation, low relief, the existence of a thin veneer of surficial sand and gravel and a deeply weathered soil profile make geologic mapping difficult.

The Atlantic Coastal Plain, which comprises the principal part of the quadrangle, is physiographically divisible into two distinct parts. The Suffolk scarp, at an elevation of about $7 \mathrm{~m}$, separates the immer Coastal Plain (west to the fall line) from the outer Coastal Plain (east to the coastal margin). The inner and outer coastal Plaln are characterized by differences between primary depositional features and subsequent erosional features. In general, the inner Coastal Plain is characterized by elevations of 7 to $53 \mathrm{~m}$ and relief of 7 to $15 \mathrm{~m}$ whereas the outer Coastal Plain is characterized by elevations below $8 \mathrm{~m}$ and relief locally to $7 \mathrm{~m}$. Broad, flat undissected areas, pocosins, form poorly drained areas between major streams in both parts of the Coastal Plain.

A fairly well integrated system of creeks and rivers drains the quadrangle. The major rivers are the Roanoke, Chowan, and James, which head in the Piedmont, and the Perquimans, Little, Pasquotank, North Landing, Elizabeth, and Nansemond, which head in the Coastal Plain. The Dismal Swamp occupies an arrea of approxlmately $5700 \mathrm{su} \mathrm{km}$ east of the Suffolk scarp and centered on the Virginia-North Carolina border.

\section{STR $\Lambda$ TIGRAPHY}

PIEDMONT

Eastern Slate Belt Rocks

Eastern Slate Belt rocks (Pzfvs) occur in the west part of the quadrangle. They consist of a sequence of low-rank metavolcanic-sedimentary rocks that may reach a thickness of over $6000 \mathrm{~m}$. The principal rock types are sericite-chlorite phyllite, slate, argillite, metagraywacke, quartzite, greenstone, and comparable metafelsites (Parker, 1968). These rocks are regionally in the greenschist facies of metamorphism.

\section{Raleigh Belt Rocks}

Rocks of the Raleigh Belt (Pzmgn) occur in the western part of the quadrangle west of Eastern Slate Belt. The rocks of the Raleigh belt are high-rank metamorphics that include biotite-muscovite gneiss and schist, commonly with interbeds of hornblende gneiss. They belong to the upper greenschist and amphibolite facies, having almandine and associated minerals. The boundary between the Raleigh Belt and the Eastern slate Belt separates rocks containing almandine and other high temperature minerals from rocks that contain chlorite, epidote, and biotite. 
Granite Plutons

Granitic plutons are exposed south and east of Roanoke Rapids, N. C., and south and north of Emporia, Virginia, in river valleys where Coastal Plain materials have been removed by fluvial erosion. In addition, major granitic plutons occur west of Roanoke Rapids and east and west of Lawrenceville, Virginia. These plutons are variable in crystal size and mineral content, but generally consist of microcline, biotite granite, and chloritic granodiorite. In Virginia they are referred to as the Petersburg Granite. In North Carolina, the plutons are commonly coarse-grained red microcline granite with little plagioclase and biotite.

Basic Rocks

A body of basic rock extends northwest from Emporia, Virginia, exposed in river valleys and continuing into the Piedmont. The rock types are amphibole chlorite schist, chloritic hornblende gneiss, and some amphibolite, chloritic diorite, and hornblende diorite.

\section{COASTAL PLAIN}

\section{Potomac Group}

The basal unit of the Virginia Coastal Plain, the Potomac Group, overlies nonconformably a highly eroded and saprolitized Precambrian and early Palezoic basement of igneous and metamorphic rocks (Piedmont). The Potomac Group was originally defined by McGee (1885) as the sediments between the Triassic redbeds (Newark formation) and the Cretaceous greensands of New Jersey. Clark and Bibbins (1897) divided the Potomac Group into four formations: Patuxent, Arunde1, Patapsco, and Raritan. The oldest sediments overlying the Piedmont in the Norfolk quadrangle are the Patuxent Formation and occur along the Nottoway River in Sussex County, Virginia.

The Potomac Group in the southern Virginia Coastal Plain consists of an alternating sequence of very light gray to white, medium to very coarse feldspathic sand, conglomerate, and silty to sandy clay with abrupt vertical and lateral variations. Common sedimentary structures are cross-beds and graded bedding. Lignitized wood and we11-preserved microflora are abundant in the clay- and silt-sized sediments. The Potamac. Group is a wedge-shaped body that ranges in thickness from a feather edge on the west to almost $550 \mathrm{~m}$ in the subsurface at Norfolk.

The Potomac Group was deposited in a complex fluvial and deltaic environment (Glaser, 1969) and can be compared with modern alluvial valley fill of the Mississippi River. Specific environments are floodplain, channel, bank, and.swamp. The Potomac Group is considered of Early Cretaceous age, based on pollen from. sediments exposed in the Hopewell area, and is assigned to pollen zone I (Barremian to Aptian) to zone II-B (lower to middle Albian) (Dischinger, 1979). 
The Aquia Formation rests unconformably on an eroded Potomac Group surface. It was named from exposures along Aquia Creek, Stafford County, Virginia by Clark (1895).

The Aquia Formation consists of massive green to black, very fine to fine, well-sorted sand. It is usually glauconitic, with the glauconite principally concentrated in burrows. It is generally less than $10 \mathrm{~m}$ thick in outcrop; however, it exceeds $30 \mathrm{~m}$ in the subsurface east of the outcrop belt. Gradational to the Aquia Formation is the Marlboro Clay, which is a massive gray to red clay. As the upper surface of the Marlboro Clay is a distinct unconformity, it is part of the underlying Aquia Formation.

The Aquia Formation contains an abundant marine invertebrate fauna dominated by a molluscan assemblage. However, fishes and reptiles are also present. The Aquia formation was deposited in relatively quiet and probably deep open marine water. The Marlboro Clay was deposited in a brackish water estuarine environment.

Calcareous nannofossils from the Aquia Formation indicate that the unit is uppermost Paleocene (T. R. Worsley, personal communication) and assignable to Zone NP 9. Sporomorph assemblages from the Marlboro Clay suggest that it is either latest Paleocene or earliest Eocene in age (Gibson and others, in press).

\section{St. Marys Formation}

The St. Marys Formation was established by Shattuck (1902) from exposures in St. Marys County, Maryland. Sediments originally referred to as the St. Marys south of the James River in Virginia have been referred to as the Claremont or Cobham Formations (Blackwelder and Ward, 1976). Because no recent work has identified which unit (Claremont or Cobham) represents the St. Marys Formation of southern Virginia, both uitits are diseuased.

The Claremont Formation is named for exposures in the vicinity of Claremont on the right bank of the James River, Surry County, Virginia. The Claremont Formation characteristically consists of gray, fine clayey sand or sandy clay. Glauconite is common in the sand faction. The thickness of the Claremont in the type area is about $8 \mathrm{~m}$.

The Claremont Formation contains a molluscan assemblage, which suggests deposition of the unit in a full marine to nearshore marine environment. The unit is considered early late Miocene, based on superposition and $\mathrm{K}-\mathrm{Ar}$ radiometric dates of the underlying Cobham Formation.

The Cobham Formation is named for exposures at Cobham Wharf on the James River, Surry County, Virginia. The unit disconformably overlies the Claremont Formation and is unconformably overlain by the Yorktown Formation. 
The Cobham Formation consists of fairly well sorted mixtures of fine to medium shell and sand. Generally, the Cobham consists of well-sorted. clayey sand and sandy clay in the central and northern parts of the depositional area, whereas the beds are poorly sorted around the periphery of the basin. In the type area, the Cobham Formation is approximately $5 \mathrm{~m}$ thick.

The Cobham Formation, which contains an abundant molluscan assemblage, is considered middle late Miocene on the basis of a $\mathrm{K}$-Ar glauconite age of $8.7 \pm 0.4 \mathrm{~m} . \mathrm{y}$. and on the basis of molluscan correlation with the Miocene of Florida. The diverse molluscan assemblage suggests deposition in a nearshore to full marine environment.

\section{Yorktown Formation}

The Yorktown Formation was named by Clark and Miller (1906) for exposures of fossiliferous sand and clay on the York River at Yorktown, Virginia. Blackwelder and Ward (1976) divided the Yorktown into four members from study of exposures in Virginia; however, they have not been traced or mapped into northeastern North Carolina. Consequently, the Yorktown Formation is not subdivided for purposes of this report or on the accompanying geologic map.

The Yorktown Formation represents one of the most extensive transgressions in the Norfolk quadrangle. The unit, therefore, occurs over most of the inner Coastal Plain between the fall line and Suffolk scarp. Several incised rivers in the outer Coastal Piain also expose the Yorktown Formation, and it also occurs as outliers along the fall 1 ine in the Virginia Piedmont. The lithology of the formation ranges from gray- to blue-colored shell marl, molluscan limestone, fine to coarse sand, and massive clay with interbedded micaceous sand. In the type area the thickness of the Yorktown Formation is about $17 \mathrm{~m}$; in the subsurface of eastern North Carolina it reaches a thickness of greater than $120 \mathrm{~m}$.

The Yorktown Formation represents deposition in a warm temperate climatic zone. Specific environmento arc: shallow marine shelf, open bay, sound, or lagoon; and low salinity bay or estuary. The depth of deposition was probably less than $30 \mathrm{~m}$ (Bailey, 1970).

Traditionally, the Yorktown Formation has been considered late Miocene (Cooke, 1936; Richards, 1950; and Copeland, 1964). However, DuBar and others (1974a), Baum and Wheeler (1977), and Blackwelder and Ward (1979) suggest the formation is Pliocene.

Undifferentiated Late Pliocene, Pleistocene and Holocene Sediments

Late Pliocene to Pleistocene sediments occur west of the Suffolk scarp in Virginia and include the Sedley Formation, Bacons Castle Formation, the "Moorings. Unit," and Windsor Formation. 
The Sedley Formation, which unconformably overlies the Yorktown Formation, was named by Moore (1956) and consists of sandy silt and fine sand with thin layers of silty clay. Near major streams it coarsens to clayey, fine to medium sand with organic matter, and it. also coarsens distinctly westward. The Sedley Formation occurs principally west of the Suffolk scarp; however, within $2 \mathrm{~km}$ east of the scarp, it is present as thin, isolated remnants in the subsurface. The thickness of the Sedley ranges from less than a meter just east of the Suffolk scarp to more than $9 \mathrm{~m}$ west of the scarp; it averages about $4 \mathrm{~m}$ in thickness.

The Sedley Formation contains a few marine fossils and therefore its origin is partly marine. Thicker, coarser, and organic-rich parts of the Sedley suggest a fluvial-estuarine origin. The stratigraphic position and the fossils of the unit suggest a Pliocene or early Pleistocene age for the unit.

The Bacons Castle Formation was named by Coch (1968) and is composed of clayey sand, silty sand, pebble gravel, and cobble gravel. It is present on the surface and in the subsurface only west of the Suffolk scarp where it unconformably overlies the Yorktown and Sedley Formations. The maximum thickness of the Bacons Castle is less than $9 \mathrm{~m}$; it thickens toward major streams.

The complex intertonguing of facies, the lack of fossils, oxidation, eastward-dipping cross laminae, westward coarsening, and thickening near present major streams suggest a fluvial environment of deposition for the unit (Oaks and Coch, 1973). The age of the Bacons Castle is uncertain; however, a probably Pliocene or Pleistocene age is indicated by the stratigraphic position of the unit.

The "Moorings Unit" was introduced informally by Oaks and Coch. (1973) for a linear body of fine sand along the Surry scarp that interfingers westward with a thin clayey s1lt. The sand has a thickness up to almost $10 \mathrm{~m}$ and is unfossiliferous, fine, and slightly silty. The clayey silt ranges in thickness from less than $2 \mathrm{~m}$.to greater than $6 \mathrm{~m}$. Barrier and lagoonal environments of deposition for the sand and silt of the "Moorings Unit" are indicated. Stratigraphic position suggests that the "Moorings Unit" is Pleistocene.

The Windsor Formation was proposed by Coch (1968) for the silty sand that occurs east of the Surry scarp. It unconformably overlies the "Moorings Unit" along the Surry scarp and unconformabiy overties the Bacons Castle, Sedley, and Yorktown Formations between the Susty and Suffolk scarps. The unit does not occur east of the Suffolk scarp. The maximum thickness of the formation is about $10 \mathrm{~m}$. The unit consists of lower light-gray, medium to coarse, unfossiliferous sand and gravel which grades upward into unfossiliferous, thick-bedded clayey sand, silty sand, and silty clay. On the basis of the good sorting and rounding of the sediment, coarse grain size, its unoxidized color, westward limit at the Surry scarp, and the probable beach ridges along the Surry scarp, a nearshore-marine environment of deposition for the lower member is suggested. A lagoonal environment of deposition is 
inferred from the flat depositional morphology, the blanket-like distribution, fine grain size, unoxidized aspect, and lack of sediment structures for the upper part of the Windsor Formation. A middle Pleistocene age is assigned to the Windsor Formation (Oaks and Coch, 1973).

The Great Bridge, Norfolk, Kempsville, Londonbridge, and Sand Bridge Formations are principally restricted to the area east of the Suffolk scarp.

The Great Bridge Formation, named by Oaks and Coch (1963) and modified by Oaks (1.965), occurs only in the subsurface east of Suffolk scarp. It consists of lower sand and gravel and an overlying clay and sand that unconformably overlies the Yorktown Formation. The lower lithology ranges up to almost $8 \mathrm{~m}$ in thickness and the upper lithology to almost $17 \mathrm{~m}$. Deposition of the Great Bridge Formation in a fresh-water estuarine environment is indicated by the occurrence of peat in the lower part and the clayey silt of the upper part. A late Pleistocene age is assigned to the Great Bridge Formation.

The Norfolk Formation was named by Clark and Miller (1906) for exposures in Norfolk County, Virginia. The unit unconformably overlies the Yorktown, Sedley, Bacons Castle, Windsor, and Great Bridge Formations. It is mainly present east of the Suffolk scarp; however, it occurs west of the scarp in the Great Dismal Swamp. The maximum thickness of the Norfolk Formation is about $15 \mathrm{~m}$. The formation has a lower member composed of bluish-gray, fine to very coarse quartz sand with minor gravel; it reaches almost $3 \mathrm{~m}$ in thickness. The member occurs throughout the entire area where the Norfolk Formation is present east of the Suffolk scarp. An upper member, divisible into eight mappable units designated by the dominant lithologic aspect (Coch, 1968), forms the major part of the formation. The maximum thickness of the Norfolk Formation is about $15 \mathrm{~m}$.

The Norfolk Formation was deposited in a shallow-marine environment east of the Suffolk scarp, whereas Norfolk sediments west of Suffolk scarp were deposited in fluvial and estuarine systems and include the following specific environments: open bay, lagoonal, marsh to tidal flat. The Norfolk Formation is late Pleistocene age. Uranium ages of corals indicate an age of about 70,000 years. The Norfolk. Formation occupies the same position as the Flanner Beach Formation in the Neuse River area of North Carolina.

The Kempsville and Londonbridge Formations were named by Oaks and Coch (1963) and are used for linear sand or gravel bodies that overlie the Norfolk Formation in the Hickory scarp and Oceana ridge, respectively. The Kempsville Formation reaches a thickness of about $5 \mathrm{~m}$ all prubably represents deposition in beach, dune, and marsh environments. The Kempsville Formation is late Pleistocene age based on the presence of Pleistocene fossils and on $a{ }^{14} \mathrm{C}$ age greater than 40,000 years $\mathrm{b} . \mathrm{p}$. determined from a piece of driftwood collected from the type section. The tondonbridge Formation, in addition to containing sand and gravel, also contains a clay-silt facies that interfingers in the subsurface with the eand. 
The Londonbridge Formation formed in a barrier island-open lagoon complex as indicated by the sand-gravel lithology and the clay-silt lithology. A very late Pleistocene age for the Londonbridge Formation is suggested by its stratigraphic position.

The Sand Bridge Formation was named by Oaks and Coch (1963) for a terrigenous sequence of quartz sand, clayey sand, silty sand, and silty clay that occurs on the surface east of Suffolk scarp. The formation reaches a maximum thickness of about $11 \mathrm{~m}$. Characteristic 1ithologies and sedimentary structures, morphology, and stratigraphic patterns suggest a barrier-lagoonal environment of deposition within the following specific environments: lagoon, eolian, open-marine, and shoal. The Sand Bridge Formation is of late Pleistocene pre-Holocene age.

Holocene sediments include beach, dune, barrier, backbarrier, and fossiliferous sand, soft silty and clayey mud, and peat that occur along the barrier islands and the sounds. They are not differentiated from late Pleistocene sands.

\section{Surficial Deposits}

In the North Carolina part of the quadrangle, post-Yorktown sediments have not been studied and separated into formations. They are, therefore, referred to as surficial deposits and consist of a thin veneer of gravel, sand, silt, and clay that almost everywhere conceals the older formations. In Virginia they have been studied and partially mapped; therefore, they were identified and discussed under undifferentiated Pliocene, Pleistocene, and Holocene sediments above.

\section{STRUCTURAL GEOLOGY}

Coastal Plain strata in the quadrangle occur as a seaward-thickening monoclinal wedge that dips to the east at a rate of $6-10 \mathrm{~m} / \mathrm{km}$. Two major structural features involving the basement in or adjacent to the quadrangle are recognized: the Hatteras embayment in northeastern North Carolina and the Norfolk arch (Ft. Monroe high) in southeastern Virginia. The Hatteras embayment represents a major area of sedimentary thickening between the Cape Fear arch to the south and the Ft. Monroe high in Virginia. Jurassic(?) age sediments in the Esso 1 1 Hatteras well drilled at Cape Hatteras indicates that the area has actively received sediment since the Jurassic. The Ft. Monroe high is an east-west-trending structure that extends through Norfolk, Virginia. It has affected Late Cretaceous and Tertiary, deposition (Teifke, 1973). Additional structural features that have affected Coastal plain sediments in the Norfolk quadrangle include two minor north-south-trending faults that involve Eocene and Miocene strata just west of Norfolk (Cedarstrom, 1945). No other structures occur in the quadrangle. 
MINERAL RESOURCES

There are no reported occurrences of uranium, niobium, tin, beryllium, lithium, tungsten, vanadium, thorium, zircon, or rare earth minerals in the quadrangle. In addition, there are no reported igneous intrusions of pegmatites or massive sulfides in the area. There are commercial deposits of non-metallic mineral resources including sand, gravel, stone, clay, and lime currently being mined in the area. These locations are shown on the geologic map (Plate 4).

Sand, Grave1, and Crushed Stone

Sand and stone for crushing are mined in major commercial operations throughout the quadrangle. In North Carolina, sand and gravel are mined at Garysburg (Northampton County). In Virginia, sand and gravel are mined near Stoney Creek and Gray (Sussex County), near Adams Grove and Boykins Courtland (Southampton County), Benns Church and Wills Corner (Isle of Wight County), Sandy Bottom and Suffolk (Nansemond County), and at several different localities in Chesapeake and Virginia Beach.

Stone for crushing is mined in North Carolina at Weldon (Northampton County) and in Virginia near Rawlings and Lawrenceville (Brunswick County) and near Skippers (Greensville County).

$\underline{\text { Clay }}$

Clay is mined at Lawrenceville and Pleasant Shade in the Virginia part of the quadrangle for use in brick manufacture in Lawrenceville.

GEOLOGIC LITERATURE FOR THE NORFOLK QUADRANGLE

Previous Studies

Recent geologic mapping of the Norfolk quadrangle is sparse (Figure 4). No recent geologic maps have been made of the North Carolina part of the quadrangle, and on.1.y the eastern part in Virginia has received recent study. Detailed Geologic mapping in Virginia includes the work of Coch (1968, 1971) on the Benns Church, Smithfield, Windsor, Chuckatuck, Newport News South and Bowers Hill quadrangles, Oaks (1965) on the Kempsville, Princess Anne, Suffolk, Lake Drummond NW, Deep Creek, . Fentress, Pleasant Ridge, Corapeake, Lake Drummond, Lake Drummond SE, Moyock, and Creeds quadrangles, and Barker and Bjorken (1978) on the Norfolk North quadrangle.

Regional geologic mapping of the North Carolina Coastal Plain was completed by Stephenson (1923) for the Cretaceous and by Clark and others (1912) for the Tertiary. Rogers (1884) reported on the geology of the Virginias, and Clark and Miller $(1906,1912)$ reported on the geology and physiography of the Coastal Plain of Virginia. Brown and others (1972) reported on the subsurface distribution of Cretaceous and Tertiary sediments from New York to North Carolina. In Virginia, Oaks and Coch 
(1973) reported on the Post-Miocene stratigraphy and morphology of the southeastern part of the quadrangle, Teifke (1973) reported on the stratigraphy of the Lower Cretaceous through Miocene, and Onuschak (1973) on Pleistocene-Holocene environmental geology.

Other studies that have included the Norfolk quadrangle in Virginia include Wentworth (1930) on the sand gravel resources of the Virginia Coastal Plain; Cederstrom (1945) on the structural geology; Gooch and others (1960) on sources of aggregate used in highway construction; Le Van and Pharr (1963) on a magnetic survey; McLean (1966) on Miocene and Pleistocene foraminifera and ostracoda; Blackwelder and Ward (1976) on the Chesapeake Group; and Johnson (1977) on bouguer gravity.

\section{Current Research}

The Geology and Mineral Resources Section (GMRS) of the North Carolina Department of Natural and Economic Resources has divided the state into 17 multi-county planning regions that will be covered by the geologic maps. The GMRS plans to have open-file reports on the Coastal Plain by 1981 .

Current work in the quadrangle is in progress in the Piedmont of North Carolina by State University. The Coastal Plain area of the North Carolina part of the quadrangle is currently being studied by Stanley $R$. Riggs and Scott W. Snyder of East Carolina University. The Coastal Plain area of the Virginia part of the quadrangle 1s currently being studied by Wayne Newell and Lauck W. Ward of the U.S. Geological Survey and Gerald H. Johnson of the College of William and Mary.

\section{GEOLOGIC HISTORY}

The Coastal Plain Physiographic Province extends along the Atlantic Coast from southern Florlda to the Grand Banks of Newfoundland. The sediments and sedimentary rocks generally form a wedge-shaped mass that thickens from a featheredge along the fall line to a maxlmum along the coastal margin. However, the recent recognition that a basement-rooted tectonic framework has affected Coastal Plain deposition suggests that local variations in sediment thickness and lithology occur. Coastal plain sediments and rocks rest unconformably on a Paleozoic and Precambrian basement of igneous and metamorphic rock or early Mesúcuic sedimentary rock. Precambrian(?) to ear1y Paleozoic Piedmont rocks and Lower Cretaceous through Holocene sediments and sedimenlary rocks occur In the quadrangle.

The oldest Coastal Plain sediments in the quadrangle consist of complex fluvial-deltaic sand and conglomerate referred to the Potomac Group. This group, which represents the lower unit of a nonmarine succession, filled pre-existing basement luws north and south of the Fort Monroe high and generally displays thickening toward the east. 
Tiefke (1973) has mapped the distribution of the Potomac Group in the subsurface. The Arundel, Patapsco, and Raritan formations (Teifke's transitional beds) were deposited north and south of the Fort Monroe high in the Salisbury and Hatteras embayments, respectively. These transitional beds represent the final stage of a long period of terrigenous clastic sedimentation and basin filling. The transitional beds are intermediate in composition and texture between the underlying Patuxent Formation and the overlying Mattaponi Formation, and the lower contact is presumed to be one of unconformity. The transitional beds may conformably transgress the Cretaceous-Tertiary boundary.

The Paleocene Aquia Formation disconformably overlies the Potomac Group and represents the first extensive marine transgression of the Paleogene. The" top of the unit, which is marked by a distinctive clay known as the Marlboro Clay, represents a major regression that may transgress the Paleocene-Eocene boundary. The Marlboro Clay underlies the Eocene Nanjemoy Formation in the subsurface of the northern part of the quadrangle.

Upper Eocene to Miocene time is marked by a major marine transgression that resulted in deposition of the Calvert Formation over most of the Coastal Plain of Virginia. Although the Calvert Formation is not exposed in outcrop, it has been mapped in the subsurface of the quadrangle by Teifke (1973). During the late Miocene, the St. Marys Formation was deposited over most of the Coastal Plain in a full marine to nearshore marine environment.

During the Pliocene, one of the most extensive marine transgressions of the Tertiary occurred and is represented by the Yorktown Formation. The unit, which crops out over much of the inner Coastal Plain between the fall line and the Surry scarp represents deposition in a warm climatic zone in shallow marine shelf to estuary or bay environments.

During the late Pliocene, Pleistocene, and Holocene, sediments of various depositional environments were deposited unconformably on the Yorktown Formation. During the late Pliocene-early Pleistocene, sea level rose to a maximum of about $23 \mathrm{~m}$ and deposited the marginal marine, fluvial-estuarine Sedley Formation over most of the Coastal Plain of the quadrangle. Although the unit was deposited west of the Suffolk scarp to near the fall line, it is preserved principally as erosional remnants east of the scarp. As sea level fell, the Bacons Castle Formation was deposited west of the Suffolk scarp. Although the boundary between the underlying Yorktown and Sedley Formations and the overlying Bacons Castle Formation is unconformable, the fluvial nature of the Bacons Castle and its restriction to the Coastal Plain west of the Suffolk scarp suggests that the unit was deposited during regression of an early Pleistocene sea. 
During the middle Pleistocene, sea level rose to the Surry scarp and deposited the transgressive Windsor Formation disconformably on the "Moorings Unit", Bacons Castle, Sedley, and Yorktown Formations. As probable beach ridges occur along the Surry scarp, the westward limit of the Windsor Formation is depositional and reflects the height to which sea level rose.

During the late Pleistocene, sea level rose to the Suffolk scarp and deposited the Great Bridge, Norfolk, Kempville, Londonbridge, and Sand Bridge Formations disconformably on middle Pleistocene to Pliocene units. Where the Suffolk scarp was breached, sediments assigned to the Norfolk Formation were deposited west of the scarp in the Great Dismal Swamp. 


\section{REFERENCES}

Bailey, R. H., 1970; Relationships between pelecypod assemblages and sediment types in the Yorktown Formation.along the Chowan River, northeastern North Carolina (M.S. thesis): Chapel Hill, University of North Carolina at Chapel Hill, $56 \mathrm{p}$.

Bailey, R. H., 1973, Paleoenvironment, paleoecology, and stratigraphy of molluscan assemblages from the Yorktown Formation (Upper Miocene-Lower Pliocene) of North Carolina (Ph.D. thesis): Chapel Hill, University of North Carolina at Chapel Hill, 110 p.

Bain, G. L., 1970, Geology and groundwater resources of New Hanover County, North Carolina: North Carolina Department of Water and Air Resources Bulletin 17, 79 p.

Barker, W. J., and Bjorken, E. D., 1978, Geology of the Norfolk North quadrangle, Virginia: Virginia Division of Mineral Resources Publication 8.

Bartlett, C. S., 1967, Geology of the Southern Pines quadrangle, North Carolina (M.S. thesis): Chapel Hill, University of North Carolina at Chapel Hill, $101 \mathrm{p}$.

Baum, G. R., 1977, Stratigraphic framework of the middle Eocene to lower Miocene formations of North Carolina (Ph.D. thesis): Chapel Hill, University of North Carolina at Chapel Hill, $139 \mathrm{p}$.

Baum, G. R., and Wheeler, W. H. 1977, Cetaceans from the St. Marys and Yorktown formations, Surry County, Virginia: Journal of Paleontology, v. 51 , p. 492-504.

Baum, G. R., Harris, W. B., and Zullo, V. A., 1978a, Stratigraphic revision of the exposed middle Eocene to lower Miocene formations of North Carolina: Southeastern Geology, v. 20. p. 1-19.

Baum, G. R., Harris, W. B., and Drez, P. E., 1978b, Dolomitization of the middle Eucene Castle Hayne Llmestone, North Carolina, U.S.A.: 10th International Conference on Sedimentology, Jerusalem, Abstract with Programs, p. 59-60.

Baum, G. R., Harris, W. B., and Zullo, V. A., 1979a, Historical review of Eocene to early Miocene stratigraphy, North Carolina, in Baum and others (eds.); Structural and stratigraphic framework for the Coastal Plain of North Carolina: Field Trip Guidebook, Carolina Geological Society, p. 1-15.

Baum, G. R., Harris, W. B., and Zullo, V. A., 197.9b, Structural and stratigraphic framework for the Coastal Plain of North Carolina: Field Trip Guidebook, Carolina Geological Society, 111 p. 
Baum, G. R., and others, 1979c, Tectonic history and correlation of the Eocene strata of the Carolinas: Preliminary report, in Baum and others (eds.); Structural and stratigraphic framework for the Coastal Plain of North Carolina: Field Trip Guidebook, Carolina Geological Society, p. 87-94.

Benson, P. H., 1968, The depositional environment of the Upper Cretaceous Black Creek Formation in North and South Carolina (Ph.D thesis): Chapel Hil1, University of North Carolina at Chape1 Hill, 149 p.

Berggren, W. A., 1972, A Cenozoic time scale - some implications for regional geology and paleobiogeography: Lethaia, v. 5, p. 195-215.

Berry, E. W., 1914, The Upper Cretaceous and Eocene floras of South Carolina and Georgie. J.S. Ceological. Survey Professional Paper 84,200 p.

Blackwelder, B., 1971, Cluster analysis of the molluscan assemblages from the Duplin (upper Mlocene) and Waccamaw Formation (lower Pliocene), North and South Carolina (M.S. thesis): George Washington University $43 \mathrm{p}$.

Blackwelder, B. W., and Ward, L. W., 1976, Stratigraphy of the Chesapeake Group of Maryland and Virginia: Geological Society of America, Joint Northeast-Southeast Meeting, Guidebook for field trip 7b, 55 p.

Blackwelder, B. W., and Ward, L. W., 1979, Stratigraphic revision of the Pliocene deposits of North and South Carolina: South Carolina Geological Notes, v. 23, p. 33-49.

Bonini, W. E., and Woollard, G. P., 1960, Subsurface geology of North Carolina-South Carolina coastal Plain from selsmle dala: All. Assucialiun of l'elioleuï Geologists Dulletin, v. 44, p. 298315.

Brett, C. E., 1961, Paleoecological and faunal analysis of some fossil assemblages of the Cretaceous Black Creek and Pee Dee Formations (M.S. thesis): Chapel H111, University North Carolina at Chapel Hill, $120 \mathrm{p}$.

Brett, C. E., and Wheeler, W. H., 1961, A biostratigraphic evaluation of the Snow Hill Member, Upper Cretaceous of North Carolina: Southeastern Geology, v. 3, p. 49-132.

Brown, P. M., 1958, Well logs from the Coastal Plain: of North Carolina: Department of Conservation Development, Division of Mineral Resources Bulletin 73, 87 p.

Brown, P. M., Miller, J. A., and Swain, F. M., 19\%2, Structural and stratigraphic framework, and spatial distribution of permeability of the Atlantic Coastal Plain, North Carolina to New York: U.S. Geological Survey Professional Paper 796, 79 p. 
Brown, P. M., Brown, D. L., Shufflebarger, T. E., and Sampair, J. L., 1977, Wrench-style deformation in rocks of Cretaceous and Paleocene age, North Carolina Coastal Plain: North Carolina Department of Natural and Economic Resources, Division of Earth Resources Special Publication 5, $47 \mathrm{p}$.

Campbell, L., Campbell, S., Colquhoun, D., Ernissee, J., and Abbott,. W., 1975, Plio-Pleistocene faunas of the central Carolina Coastal Plain: South Carolina Geological Notes, v. 19, p. 51-124.

Canu, F., and Bassler, R. S., 1920, North American early Tertiary Bryozoa: U.S. National Museum Bulletin 106, 879 p.

Carlson, T. W., 1976, Opaline claystones in the Paleocene of southeastern North Carolina (M.S. thesis): University of Minnesota, 73 p.

Cederstrom, C. W., 1945, Structural geology of southeastern Virginia: American Association of Petroleum Geologists Bulletin, v. 29, p. 71-95.

Cheetham, A. H., 1961, Age of the Castle Hayne Fauna (Eocene) of North Carolina: Journal of Paleontology, v. 35, p. 394-396.

Clark, W. B., 1895, Cretaceous deposits of the northern half of the Atlantic Coastal Plain: Geological Society of America Bulletin, v. 6, p. 479-482.

Clark, W. B., 1909, Some results of an investigation of the coastal plain formation of the area between Massachusetts and North Carolina: Geological Society of America Bulletin, v. 20, p. 646-654.

Clark, W. B., and Bibbins, A. B., 1897, The stratigraphy of the Potomac Group in Maryland: Journal of Geology, v. 5, p. 179-506.

Clark, W. B., and Miller, B. L., 1906, A brief summary of the geology of the Virginia Coastal Plain, in Ries, H., The clay deposits of the Virginia Coastal Plain: Virginia Geological Survey Bulletin 4, $274 \mathrm{p}$.

Clark, W. B., Miller, B. L, Stephenson, L. W., Johnson, B. L., and Parker, H. N., 1912, The Coastal Plain of North Carolina: North Carolina Geological and Economic Survey, v. 3, pt. 1, 372 p.

Coch, N. K., 1965, Post-Miocene stratigraphy and morphology, inner Coastal Plain, southeastern Virginia: Office of Naval Research, Geography Branch, Technical Report 6, 97 p.

Coch, N. K., 1968, Geology of Benns Church, Smithfield, Windsor, and Chuckatuck quadrangles, Virginia: Virginia Division of Mineral Resources Report Investigation 17, $39 \mathrm{p}$. 
Coch, N. K., 1971, Geology of the Newport News South and Bowers Hill quadrangles, Virginia: Virginia Division of Mineral Resources Report Investigation $28,26 \mathrm{p}$.

Colquhoun, D. J., 1965, Terrace sediment complexes in central South Carolina: Atlantic Coastal Plain Geological Association, Sixth Annual Field Conference, Guidebook, 62 p.

Colquhoun, D. J., 1974, Cyclic surficial stratigraphic units of the middle and lower Coastal.Plains, central South Carolina; in Oaks, R. Q., and DuBar, J. R., (eds.), Post-Miocene stratigraphy central and southern Atlantic Coastal Plain: Utah State University Press, Logan, Utah, p. 179-190.

Colquhoun, D. J., Heron, S. D., Johnson, H. S., Pooser, W. K., and Siple, G. E., 1969, Up-dip Yaleüene-Tocent thtaligraphy of Sonth Carolina reviewed: South Carolina Geologic Notes, v. 13, n. 1, p. 1-25.

Cooke, C. W., 1936, Geology of the coastal. plain of South Carolina: U.S. Geological Survey Bulletin 867, 196 p.

Cooke, C. W., 1959, Cenozoic echinoids of eastern United States: U.S. Geological Survey Professiona1 Paper 321, 106 p.

Cooke, C. W., Gardner, J., and Woodring, W. P, 1943, Correlation of the Cenozoic formations of the Atlantic and Gulf Coastal Plain and the Caribbean region: Geological Society of America Bulletin, v. 54, p. $1713-1724$.

Cooke, C. W., and MacNeil, F. S., 1952, Tertiary stratigraphy of South Carolina: U.S. Geological Survey Professional Paper, 243-B, p. 19-29.

Cooley, T. W., 1970, Post-Cretaceous stratigraphy of the central Sandlitls leyiun, North and South Carolina (Ph.n. thesis): Chapel Hill, University of North Carolina at Chapel Hill, 137 p.

Copeland, C. W., 1964, Eocene and Miocene foraminifera from two localtties in Duplin County, North Carolina: Bulletin of Amerfca Paleuntology, v. 47, p. 209324 .

Cunliffe, J. E., 1968, Petrology of the Cretaceous Peedee Formation and Eocene Cast le Hayne Formation in northern New Hanover County, North Carolina (M.S. thesis): Chapel Hill, University of Nurth Carolina at Chapel Hill, $128 \mathrm{p}$.

Curran, H. A., 1968, Upper Cretaceous foraminifera and subsurface stratigraphy of the southeast North Carolina Coastal Plain (Ph.D. thesis): Chapel Hill, University of North Carolina at Chapel Hill, $246 \mathrm{p}$. 
Da11, W. H., and Harris, G. D., 1892, The Neogene of North Carolina: U.S. Geological Survey Bulletin 84, 349 p.

Daniels, R. B., Gamble, E. E., Wheeler, W. H., and Holzhey, C. S., 1972, Field trip guidebook: Carolina Geological Society and Atlantic Coastal Plain Geological Association, Annual Meetings and Field Trip, Raleigh, N.C., 36 p.

Dischinger, J. B., 1979, Late Mesozoic and Cenozoic stratigraphic and structural framework near Hopewe11, Virginia (M.S. thesis): Chapel Hill, University North Carolina at Chapel Hill, 84 p.

Doering, J. A., 1960, Quaternary surface formations of southern part of Atlantic Coastal Plain: Journal of Geology, v. 68, p. 182-202.

Dorf, E., 1952, Critical analysis of Cretaceous stratigraphy and paleobotany of Atlantic Coastal Plain: American Association of Petroleum Geologists Bulletin, v. 36, p. 2161-2184.

DuBar, J. R., 1971, Neogene stratigraphy of the lower Coastal Plain of the Carolinas: Atlantic Coastal Plain Geological Association, 12th Annual Field Conference, 128 p.

DuBar,.J. R.; and Solliday, J. R., 1963, Stratigraphy of the Neogene deposits, lower Neuse estuary, North Carolina: Southeastern Geology, v. 4, p. 213-233.

DuBar, J. R., Johnson, H. S., Thom, B., and Hatche11, W. 0., 1974a, Neogene stratigraphy and morphology, south flank of the Cape Fear arch, North and South Carolina, in Oaks, R. Q., and DuBar, J. R., (eds.), Post-Miocene stratigraphy, central and southern Atlantic Coastal Plain: Utah State University Press, Logan, Utah, p. 139-173.

DuBar, J. R., Solliday, J. R., and Howard, J. F., 1974b, Stratigraphy and morphology of Neogene deposits, Neuse River estuary, North Carolina, in Oaks, R. Q., and DuBar, J. R., (eds.), Post-Miocene stratigraphy, central and southern Atlantic Coastal Plain: Utah State University Press, Logan, Utah, p. 102-122

Fallaw, W. C., 1963, Geology of the Rocky Point, North Carolina quadrangle and an adjacent coastal area (M.S. thesis): Chapel Hill, University of North Carolina at Chapel Hill, 88 p.

Fallaw, W., and Wheeler, W. H., 1963, The Cretaceous-Tertiary boundary at the type locality of the Castle Hayne Formation: Southeastern Geology, v. 5, p. 23-26.

Fallaw, W., and Wheeler, W. H., 1969, Marine fossiliferous Pleistocene deposits in southeastern North Carolina: Southeastern Geology, v. 5, p. 23-26. 
Fallaw, W., and Wheeler, W. H., 1969, Marine fossiliferous Pleistocene deposits in southeastern North Carolina: Southeastern Geology, v. 10 , p. $35-54$.

Ferenczi, I., 1959, Structural control of the North Carolina Coastal Plain: Southeastern Geology, v. 1, p. 105-116.

Gibson, T. G., 1967, Stratigraphy and paleoenvironment of the phosphatic Miocene strata of North Carolina: Geological Society of America Bulletin, w. 78, p. 631-650.

Gibson, T. G., and others, (in press), Biostratigraphy of the Tertiary strata in the Oak. Grove, Virginia, core hole: Virginia Division of Minera $\perp$ Kesources.

Glaser, J. D., 1969, Petrology and origin of Potomac and Magothy (Cretaceous) sediments, middle Atlantic Coastal Pla1n: Maryland Geological Survey Report of Investigation 11, $101 \mathrm{p}$.

Guoch, E. O., Wood, R. S., Parrott, W. T., 1960, Sources of aggregate used in Virginia Highway Construction: Virginia Division of Mineral Resources, Mineral Resources Report 1, 65 p.

Harris, W. B., 1975, Stratigraphy, petrology, and radiometric age (Upper Cretaceous) of the Rocky.Point Member, Peedee Formation, North Carolina (Ph.D. thesis): Chapel Hill, University of North Carolina at Chapel Hill, $190 \mathrm{p}$.

Harris, W. B., 1976, Rb-Sr glauconite isochron, Maestrichtian unit of Peedee Formation (Upper Cretaceous), North Carolina: Geology, v.4, p. 761-762.

Harris, W. R., 1.978a, External morphology, a guide to recognition of glauconite origins and effects on Kb-Sr glauconlite ages: Pinal Repuit, North Carolina Board of Srienre and Technology, $16 \mathrm{p}$.

Harris, W. B., 1978b, Stratigraphic and structural analysis of the Rocky Point Member of the Cretaceous Peedee Formation, North Carolina: Southeastern Geology, v. 19, p. 207-230.

Harris, W. B., and Bottino, M. L., 1974, Rb-Sr study of Cretaceous lobate glauconite pellets, North Carolina: Geological Society of America Bulletin, v, 85, p. 1475-1478.

Harris, W. B., and Baum, G. R., 1977, Foraminifera and Rb-Sr glauconite ages of a Paleocene Beaufort Formation outcrop in North Carolina: Geological Society of America Bulletin, v. 88, p. 869-872.

Harris, W. B., Zu1lo, V. A., and Baum, G. R., 1978, structural control of Mesozoic-Cenozoic deposition, North and South Carolina Coastal Plain: American Association for the advancement of Science, Annual Meeting, Houston, Texas, p. 106. 
Harris, W. B., Zu11o, V. A., and Baum, G. R., 1979a, Tectonic effects on Cretaceous, Paleocene, and early. Neogene sedimentation, North Carolina, in Baum and others (eds.), Structural and stratigraphic framework for the Coastal Plain of North Carolina: Field Trip Guidebook, Carolina Geological Society p. 17-29.

Harris, W. B., Fullagar, P. D., and Dischinger, J. B., 1979b, Rb-Sr glauconite ages and revisions of the Eocene time-scale, southeastern Atlantic Coastal Plain (abs.): Geological Society of America, Annual Meeting, San Diego, p. 439.

Heron, S: D., 1958, The stratigraphy of the outcropping basal Cretaceous formations between the Neuse River, North Carolina and Lynches River, South Carolina (Ph.D thesis): Chapel Hill, University of North Carolina at Chapel Hill, 155 p.

Heron, S. D., and Wheeler, W. H.; 1964, The Cretaceous formations along the Cape Fear River, North Carolina: Atlantic Coastal Plain Association Guidebook 5th America Field Conference, Durham, N. C., Duke University, $55 \mathrm{p}$.

Heron, S. D., Sw1ft, D. J. P., and Di11, C. E., 1968, Graded rhythmic bedding in the Cape Fear Formation, Carolina Coastal Plain: Sedimentology, v. 11, p. 39-52.

Hersey, J. B, Edwards, R. S., Johnson, H. R., and Bunce, E. T., 1955, Seismic observations in deep and shallow water southeast of North Carolina and South Carolina (abs.): Geological Society of America Bulletin, v. 66. p. 1573.

Holland, T. H., 1974, Geology, vertebrate fossils and environmental. controls, Lee Creek phosphate mine, North America (M.S. thesis): Houston, University of Houston.

Howard, J. F., 1966, Biostratigraphy and paleogeology of the Duplin (late Miocene) and Waccamaw (Pliocene) formations of North and South Carolina (Ph.D thesis): Bloomington, Indiana University, $166 \mathrm{p}$.

Howard, J. F., 1974, Neogene microfaunas in the Cape Fear Arch area, in Oaks, R. Q., and DuBar, J. R. (eds.), Post-Miocene stratigraphy central and southern Atlantic Coastal Plain: Utah State University Press, Logan, Utah, p. 123-138.

Ibrahim, Y. K., 1973, Paleocurrents and physical sedimentary history of outcropping Middendorf sediments south of Cape Fear River in North Carolina (Yh.D thesis): Chapel Hill, University of North Carolina at Chapel Hil1, 147 p.

Johnson, H. S., and DuBar, J. R., 1964, Geomorphic elements of the area between the Cape Fear and Pee Dee Rivers, North and South Carolina. Southeastern Geology, v. 6, no. 1, p. 37-48. 
Johnson, G. H., 1976, Geology of the Mulberry Island, Newport News North, and Hampton quadrangles, Virginia: Virginia Division of Minerals Resources Report Investigations 41, $72 \mathrm{p}$.

Johnson, S. S., 1977, Gravity map of simple bouguer gravity anomaly in Virginia: Virginia Division of Mineral Resources, 1:500,000.

Jorgenson, E C, 1969, Surface and subsurface geology of the Dovesville and Mont Clare quadrangles in South Carolina (M.S. thesis): Durham, North Carolina, Duke University, $66 \mathrm{p}$.

Kellum, L. B., 1925, The age of the Trent marl in North Carolina: Journal of Geology, v. 33, p. 183-187.

Kellum, L. B., 1926, Paleontology and stratigraphy of the Castle Hayne and Trent marls in North Carolina: U.S. Geological Survey Professional Paper 143, 56 p.

Kimrey, T. 0., 1964, The Pungo River Formation, a new name for middle Miocene phosphorites in Beaufort County, North Carolina: Southeastern Geology, v. 5, p. 195-205.

LeGrand, H. E., 1955, Brackish water and its structural implications in Great Carolina ridge, North Carolina: American Association of Petroleum Geologists Bulletin, v. 39, p. 2020-2037.

Le Grand, H. E., 1960, Geology and groundwater resources of WilmingtonNew Bern area: North Carolina Department of Water Resources Groundwater Bulletin 1, $80 \mathrm{p}$.

LeVan, D. C., and Pharr, R. F., 1963, A magnetic survey of the Coastal Plain in Virginia: Virginia Division of Mineral Resources Report Investigation $4,17 \mathrm{p}$.

MacCarthy, G. R., 1936, Magnetic anomalies and geologic structures of the Carolina Coastal Plain: Journal of Geology, v. 44, p. 396-406.

McGee, W. J., 1885, Geological formations underlying Washington and vicinity, in Report of Health Officer of the District of Columbla for the ycar ending June 30,1885 , p. 19-25.

McLean, J. D., 1966, Miocene and Pleistocene Foraminifera and Ostracoda of southeastern Virginia: Virginia Division of Mineral Resources Report Investigation 9, $123 \mathrm{p}$.

Malde, H. E., 1959, Geology of the Charleston phosphate area, South Carolina: U.S. Geological Survey Bulletin 1079, 105 p.

Maher, J. C., 1971, Geologic framework and petroleum potential of the Atlantic Coastal Plain and Continental Shelf: U.S. Geological Survey Professional Paper 659, 98 p. 
Miller, B. L, 1912, The Tertiary formations, in Clark, W., Miller, B. L., Stephenson, L. W., Johnson, B. L., and Parker, H. N., The Coastal Plain of North Carolina: North Carolina Geological Economic Survey, v. 3, p. 171-266.

Miller, J. A., 1971, Stratigraphic and structural setting of the middle Miocene Pungo River Formation of North Carolina (Ph.D. thesis): Chapel Hill, University of North Carolina at Chapel Hill, 82 p.

Mixon, R. B., and Pilkey, O. H., 1976, Reconnaissance geology of the submerged and emerged Coastal Plain Province, Cape Lookout area, North Carolina: U.S. Geological Survey Professional Paper 859, 45 p.

Monrad, J. R., 1972, Pee Dee River floodplain development, Mar1boro and Darlington counties, South Carolina (M.S. thesis): Durham, North Carolina, Duke University, 76 p.

Moore, W. E., 1956, Pleistocene terraces south of the James River, Virginia: Virginia Academy of Science Geology Section Guidebook, May 1956.

Mundorff, M. J., 1946, Ground water in the Halifax area, North Carolina: North Carolina Department Conservation Development, Division of Mineral Resources Bulletin 51, 9 p.

Nelson, P. F., 1964, Geology and groundwater resources of the Swansquarter area, North Carolina: North Carolina Department of Water Resources Groundwater Bulletin 4, $79 \mathrm{p}$.

Oaks, R. Q., 1965, Post-Miocene stratigraphy and morphology, outer Coastal Plain, southeastern Virginia: Office of Naval Research, Geography Branch, Technical Report 5, 240 p.

Oaks, R. Q., and Coch, N. K., 1963, Pleistocene sea levels, southeastern Virginia: Science, v. 140, p. 970-983.

Daks, R. Q., and Coch, N. K., 1973, Pust-mlocene stratigraphy and morphology, southeastern Virginia: Virginia Division of Mineral Resources Bulletin 82, 135 p.

Oaks, R. Q., and DuBar, J. R., 1974, Tentative correlation of post-Miocene units, central and southern Atlantic Coastal Plain, in Oaks, R. Q., and DuBar, J. R. (eds), Post-Miocene stratigraphy, central and southern Atlantic Coastal Plain: Utah State University Press, Logan, Utah, p. 232-245.

Onuschak, E., 1973, Pleistocene-Holocene environmental geology: Virginia Division of Mineral Resources Bulletin 83, pt. 3, p. 108-153.

Parker, J. M., 1968, Structure of easternmost North Carolina Piedmont: Southeastern Geology, v. 9, p. 117-131. 
Pusey, R. D., 1960, Geology and groundwater in the Goldsboro area, North Carolina: North Carolina Department of Water Resources Groundwater Bulletin 2, $7.7 \mathrm{p}$.

Richards; H. G., 1943, Additions to the fauna of the Trent Mar1 of North Carolina: Journal of Paleontology, v. 17, p. 518-526.

Richards, H. G. 1945, Subsurface stratigraphy of Atlantic Coastal Plain between New Jersey and Georgia: American Association of Petroleum Geologists Bulletin, v. 29, p. 885-955.

Richards, H. G., 1948, Tertiary invertebrate fossils from newly discovered 1ncalities in North and South Carolina, pt. 1: Academy of Natural Science Phil. Notulae Naturae, n. 207, 11 p.

Richards, H. G., 1950, Geology of the Coastal Plain of North Carolina: American Philosophical Society of Transactions, new series, v. 40, p.t. $1,83 \mathrm{p}$.

Rogers, W. B., 1884, A reprint of annual reports and other papers on the geningy of the Virginias: New York, D. Appleton and Co., 832 p.

Rogers, G. S., 1914, The phosphate deposits of South Carolina: U.S. Geological Survey Bulletin 580, p. 183-220.

Shattuck,G. B., 1902, Development of knowledge concerning the physical features of Cecil County; the Geology of Coastal Plain formations: Maryland Geological Survey, Cecil Co. volume, p. 31-82 and 149-194.

Sloan, E., 1904, A preliminary report on the clays of South Carolina: South Carolina Geological Survey, Series 4, Bulletin 1.

Slual, E., 1907, Geology and mlneral resources, in Handbook of South Carolina: South Carolina State Department of Agriculture, Commerce, and Immigration, 2nd Series, p. 77-145.

Sloan, E., 1908, Catalogue of the mineral localities of South Carolina: South Carolina Geological Survey, Series 4, Bulletin 2, 506 p.

Smith, A. B., 1959, Paleoecology of a molluscan tauna trom the Trent Formation: Journal of Palentology, v. 33, p. 855-871.

Spangler, W. B., 1950, Subsurface geology of Atlantic Cnasta1 Plain of North Carolina: American Association of Petroleum Geologists Bulletin, v. 34, p. 100-132.

Stephenson, L. W., 1907, Some facts relating to the Mesozoic deposits of North Carolina: Johns Hopkins Un1versity Circular, N. 3., n. 7, p. 93-99.

Stephenson, L. W., 1912, The Cretaceous, Lafayette, and Quaternary formations, in Clark, and others, The Coastal Plain of North Carolina: North Carolina Geologic Economic Survey, v. 5, 604 p. 
Straley, H. W., III, and Richards, H. G., 1950, The Atlantic Coastal Plain: 18th International Geological Congress Report, pt. 6, p. 86-91.

Sumison, C. T., 1970, Geology and groundwater resources of Pitt County, North Carolina: North Carolina Division of Groundwater Bulletin 18, Raleigh, North Carolina, 75 p.

Swift, D. J. P., 1964, Origin of the Cretaceous Peedee Formation of The Carolina Coastal Plain (Ph.D. thesis): Chapel Hill, University of North Carolina at Chapel Hill, 151 p.

Swift, D.J.P., and Heron, S. D., Jr., 1969, Stratigraphy of the Carolina Cretaceous: Southeastern Geology, v. 10, p. 201-245.

Teifke, R..H., 1973, Stratigraphic units of the Lower Cretaceous through Miocene series: Virginia Division of Mineral Resources Bulletin 83, part $1,78 \mathrm{p}$.

Textoris, D. A., 1967, Preliminary investigation of the Petrology of the Castle Hayne Limestone in Proceedings symposium on hydrology of the coastal waters of North Carolina: North Carolina University Water Resources Inst. Report 5, p. 3-23.

Textoris, D. A., Randazzo, A. F., and Thayer, P. A. 1972, Diagenesis of carbonate sediments as important non-cavern porosity controls: 24 th International Geology Congress, Montreal, sec. 6, p. 190-197.

Thayer, P. A., and Textoris, D. A., 1972, Petrology and diagenesis of Tertiary aquifer carbonates, North Carolina: Gulf Coast Geological Society Transactions, v. 22, p. 257-266.

Thayer, P. A., and Textoris, D. A., 1977, Faunal and diagenetic controls of porosity and permeability in Tertiary aquifer carbonates, North Carolina: North Carolina Department of Natural Economic Resources, Division of Mineral Resources Special Publication 7, 35 p.

Upchurch, M. L., 1973, Petrology of the Eocene Castle Hayne Limestone at Ideal Cement Quarry, New Hanover County, North Carolina (M.S. thesis): Chapel Hill, University of North Carolina at Chapel Hill, 97 p.

Upchurch, M. L., 1979, Sponge-bearing hardgrounds in the Castle Hayne Limestone, in Baum and others (eds.); Structural and stratigraphic framework for the Coastal Plain of North Carolina: Field Trip Guidebook Carolina Geologica1 Society, p. 59-64.

Vnkes, E. H.,1967, Ccnozoic Muricldae of the western Atlantic region: pt. III, Chicoreus (Phyllonotus): Tulane Stud. Geol. Paleont., v. 5, p. 133-166.

Vokes, E. H.; 1970, Cenozoic Muricidae of the western Atlantic region: pt. V, Pterynotus and Poirieria: Tulane Stud. Geol. Paleont., v. $8, p \cdot 1-50$. 
Ward, L. W., Lawrence, D. R., and Blackwelder, B. W., 1978, Stratigraphic revision of the middle Focene, 0ligocene, and lower Miocene-Atlantic Coastal Plain of North Carolina: U.S. Geological Survey Bulletin 1457-F, p. F1-F23.

Waskom, J. D., 1970, Geology and geophysics of the Lilesville granite batholith, North Carolina (Ph.D thesis): Chapel Hill, University North Carolina at Chapel Hill, 190 p.

Watkins, J. H., 1937, Origins of phosphates of South Carolina (M.S. thesis): Chapel Hill, University of North Carolina at Chapel Hill, 54 p.

Wentworth, C. K., 1930, Sand and gravel resources of the Coastal Plain of Virginia: Virginia Crenlogical Survey Bulletin 32, 146 p.

Wheeler, W. H., and Curran, H. A., 1974, Relation of Rocky Point Member (Peedee Formation) to Cretaceous-Tertiary boundary in North Carolina: American Association of Petroleum Geologists Bulletin, v. 58, p. 1751-1757.

Wolfe, J. A., 1976, Stratigraphic distribution of some pollen types from the Campanian and lower Maestrichtian rocks (Upper Cretaceous) of the Middle Atlantic States: U.S. Geological Survey Professional Paper 977, 18 p.

Woodas, N. A., 1965, Some lithologic and stratigraphic aspects of selected outcrops and P1iocene formations of North Carolina (M.S. thesis): Chapel Hill, University North Carolina at Chapel Hill, 75 p.

Woolen, I. D., and Colquhoun, D. J., 1977, The Black Creek-Peedee contact in Florence County, South Carolina: South Carolina Notes, v. 21, n. 1, p. 20-41.

Worsley, T.R, and Turco, K. P., 1979, Calcareous nannofoseils from the Lower Tertiary of North Carolina, in Baum and others (eds.); Structural and stratigraphic framework for the Coastal Plaln of North Carolina: Field Trip Guidebook, Carolina Geological Society, p. 65-72.

Yasyrev, A. P, 1966, Distribution of trace elements in glauconites of the Russian Platform: v. 168, Doklady Akad Nauk. SSSR, p. 197-199.

Zullo, V. A., and Harris, W. B., 1978, Relict shoreline features: A key to modern processes: Final Report to Lhe Marine Sricnces Council, University of North Carolina, $26 \mathrm{p}$.

Zu11o, V. A, 1979, Biostratigraphy of Eocene through Miocene Cirr1pcdia, North Carolina Coastal Plain, in Baum and others (eds.); Structural and stratigraphic framework for the Coastal Plain of North Carolina: Field Trip Guidebook, Carolina Geological Society, p. 73-85. 
Zullo, V. A., and Harris, W. B., 1979, Plio-Pleistocene crustal warping in the outer Coastal Plain of North Carolina, in Baum and others (eds.); Structural and stratigraphic framework for the Coastal Plain of North Carolina: Field Trip Guidebook, Carolina Geological Society, p. 31-40. 


\section{THIS PAGE}

\section{WAS INTENTIONALLY \\ LEFT BLANK}




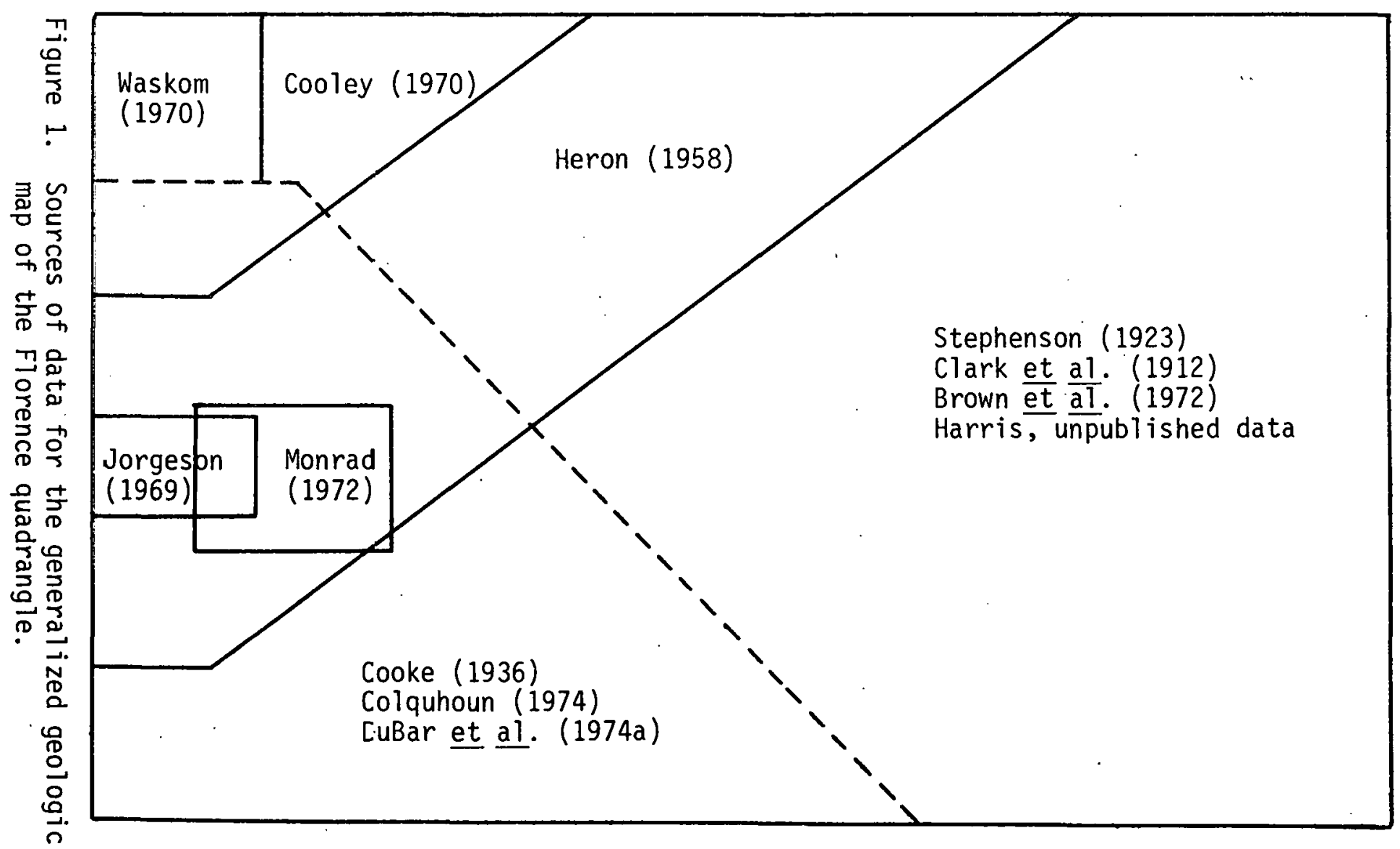




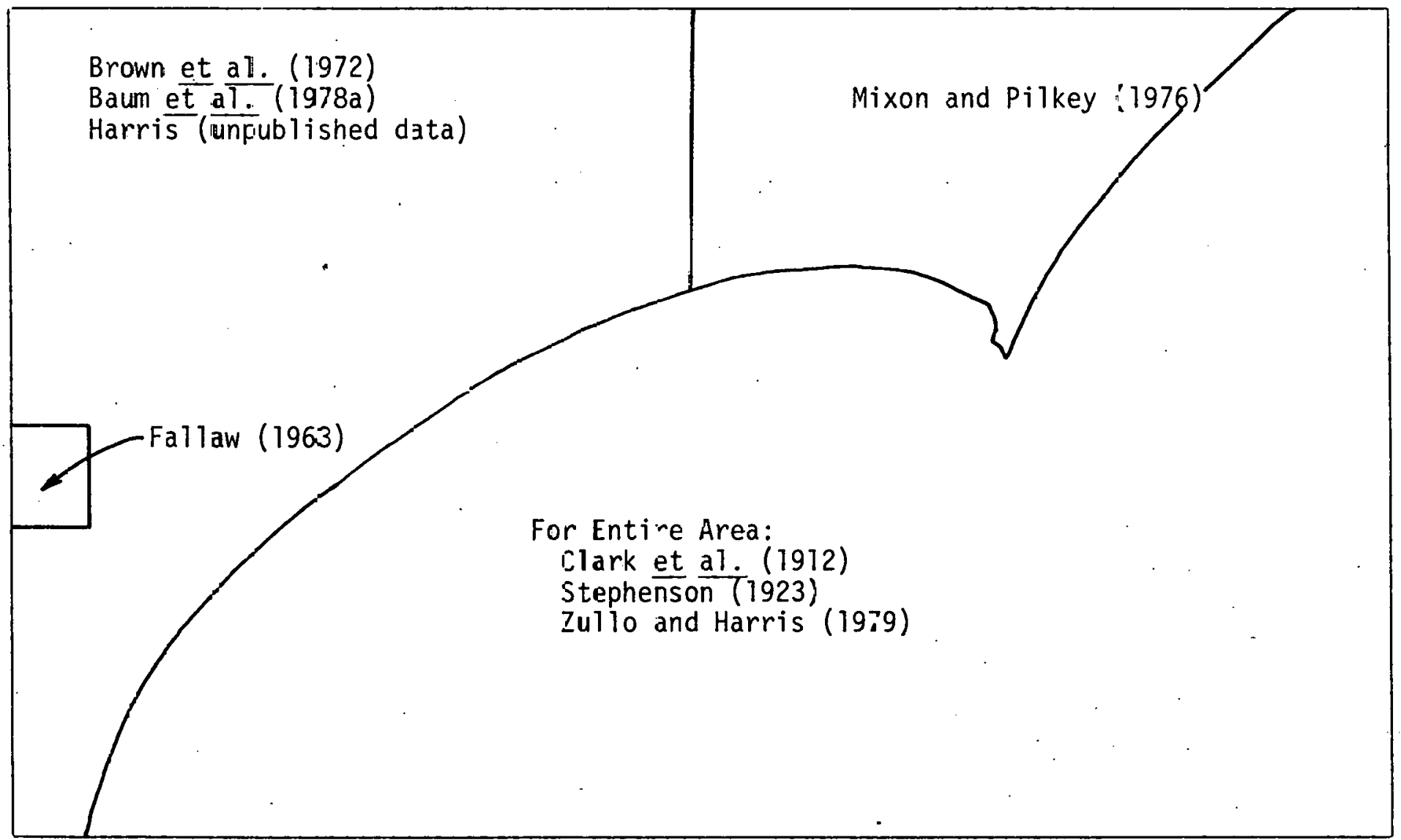

Figure 2. Sources of data for the generalized geologic map of the Beaufort quadrangle. 


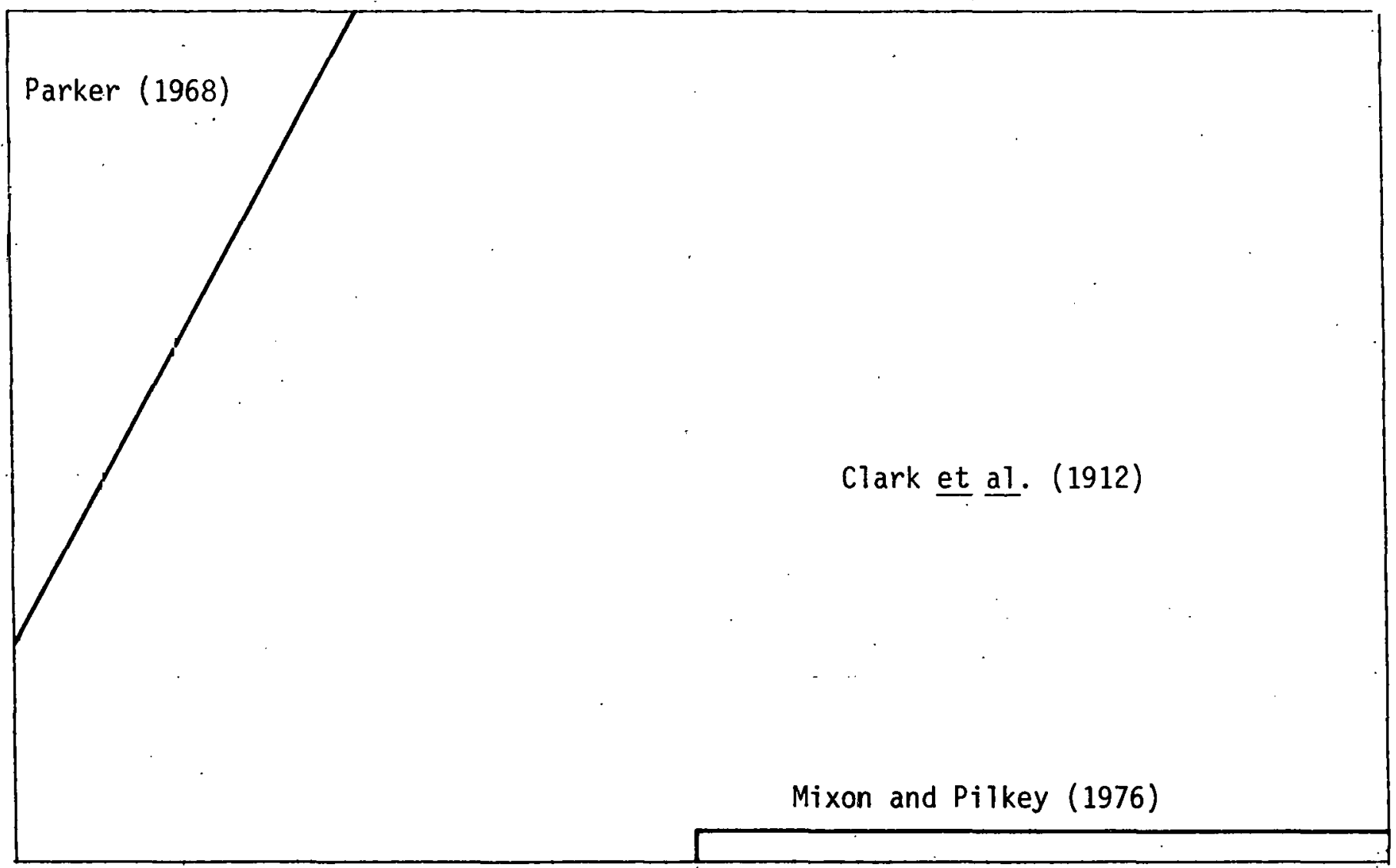

Figure 3 - Sources of data for the generalized geologic map of the Rocky Mount quadrangle. 


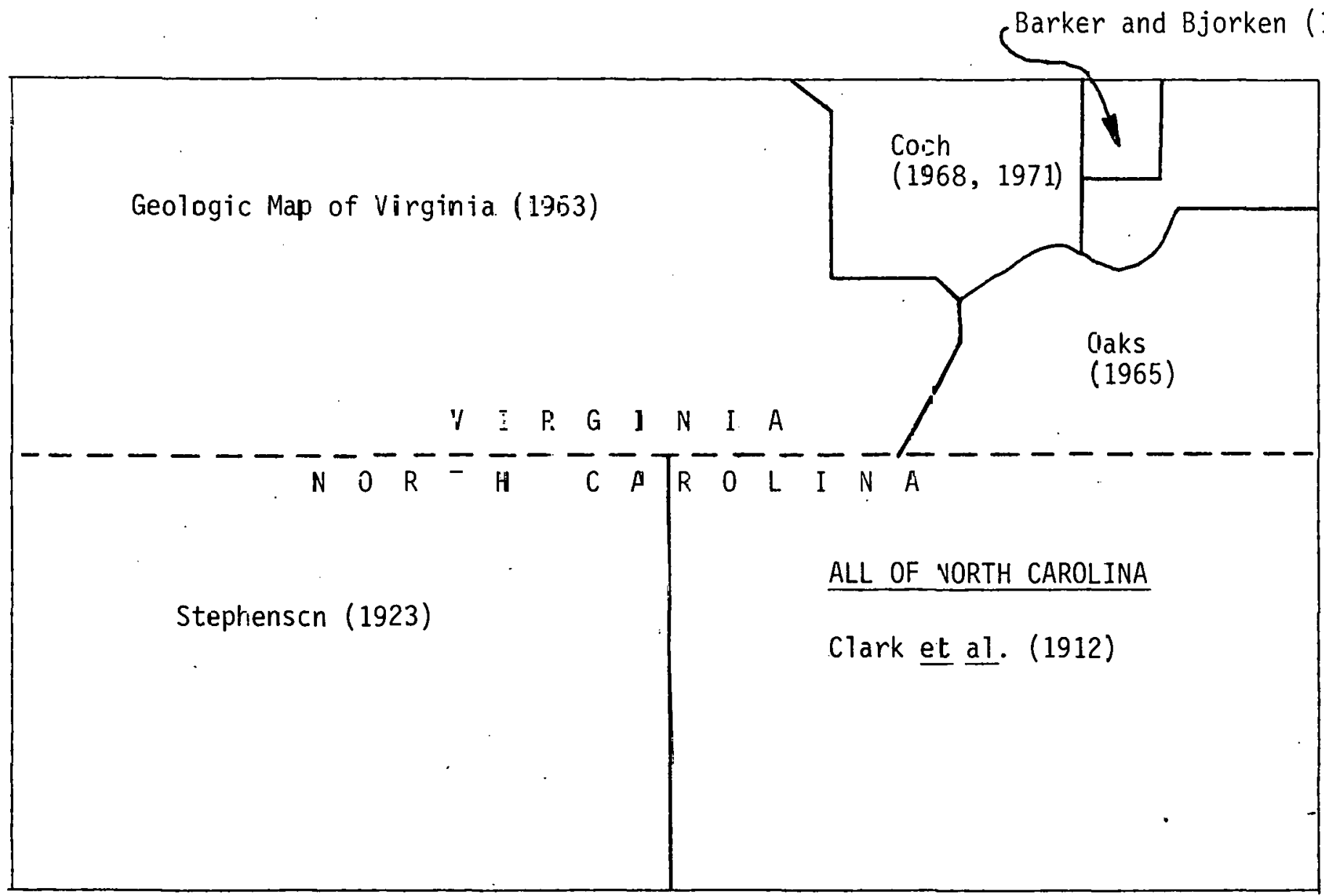

Figure 4. Sources of data for the generalized geologic map $0=$ the Norfolk quadrangle. 
GENERALIZED GEOLOGIC MAP

OF THE
RT QUADRANGLE

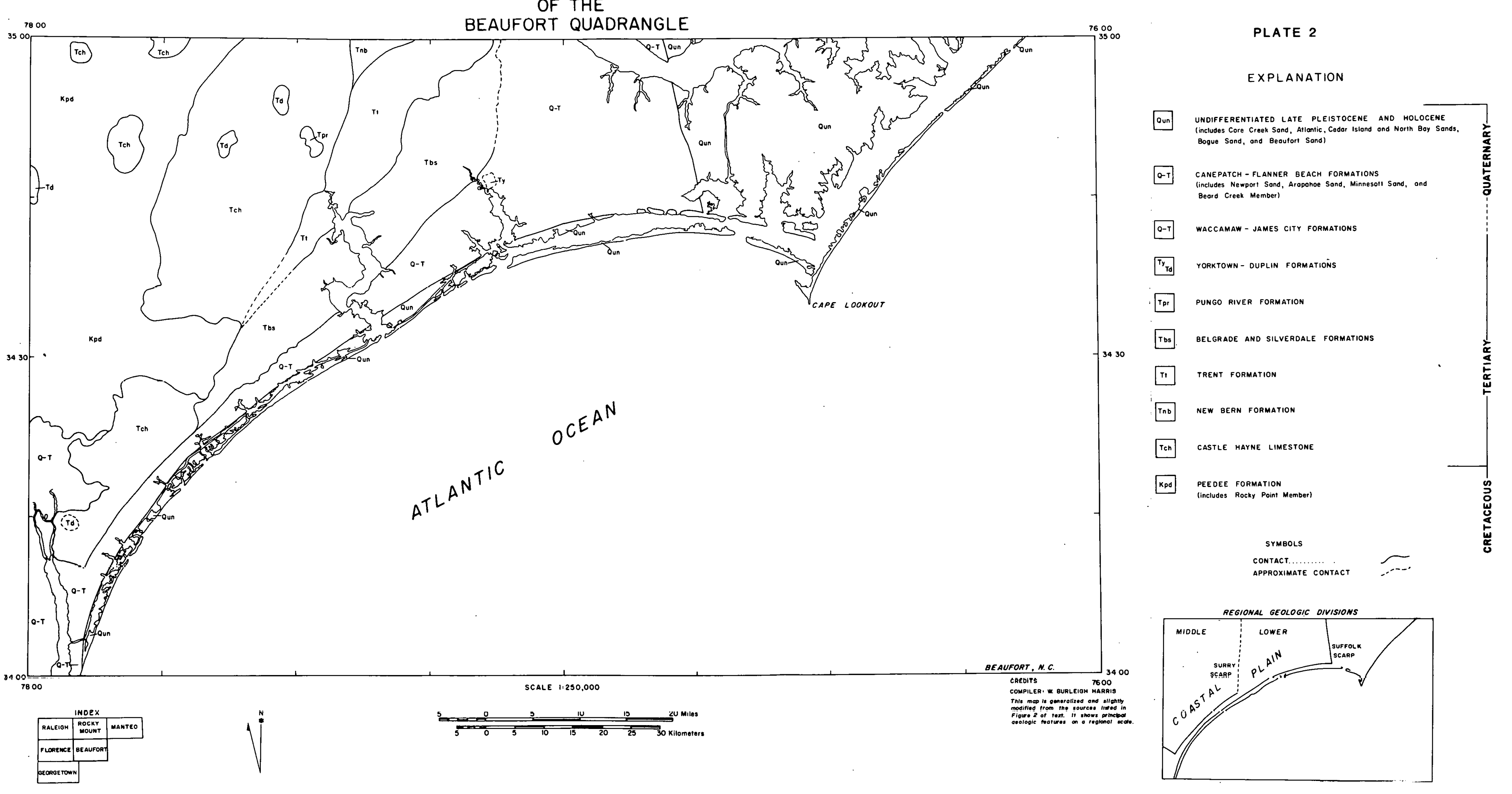




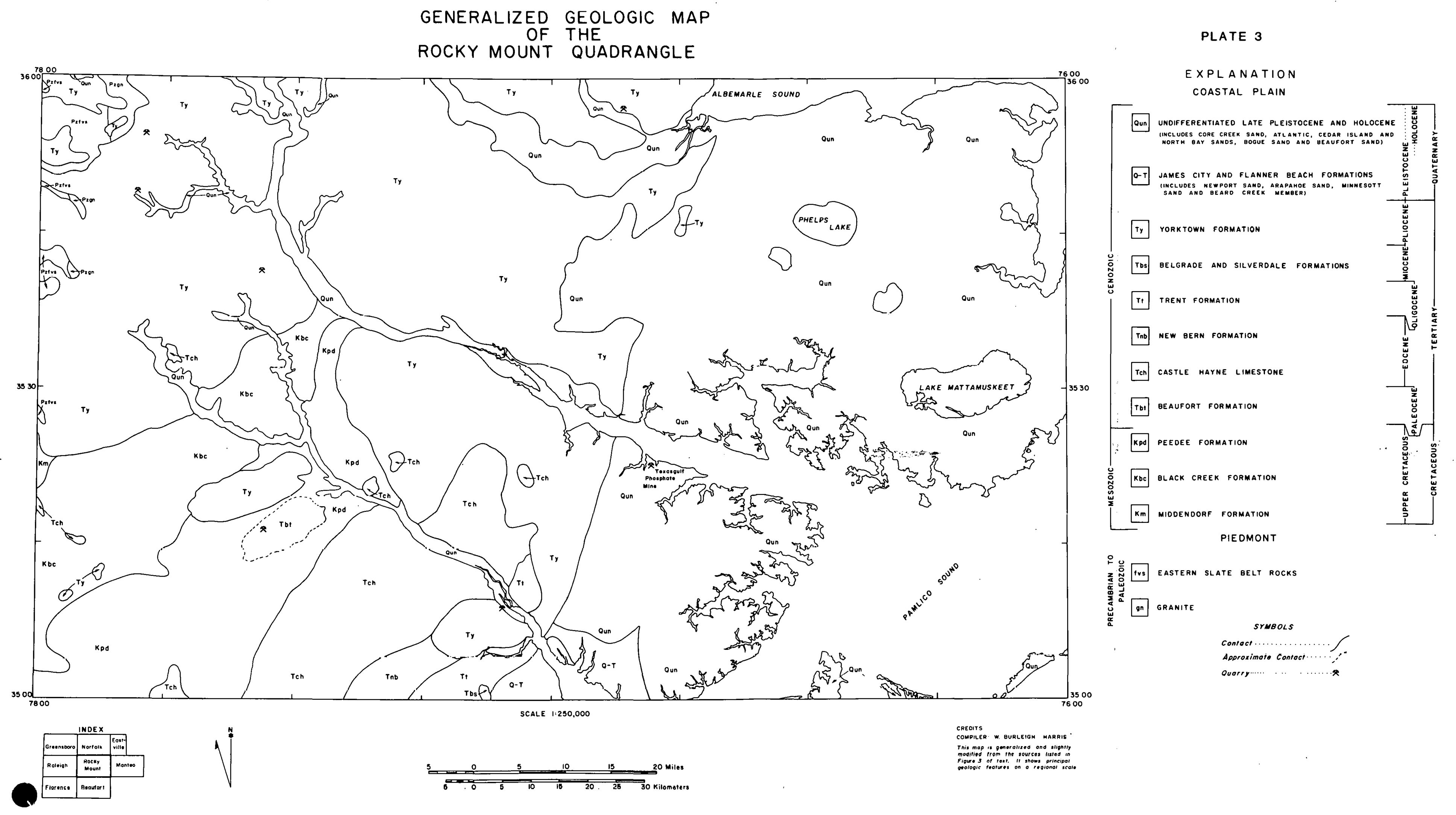


GENERALIZED GEOLOGIC MAP

NORFOLK QUADRANGLE

PLATE 4

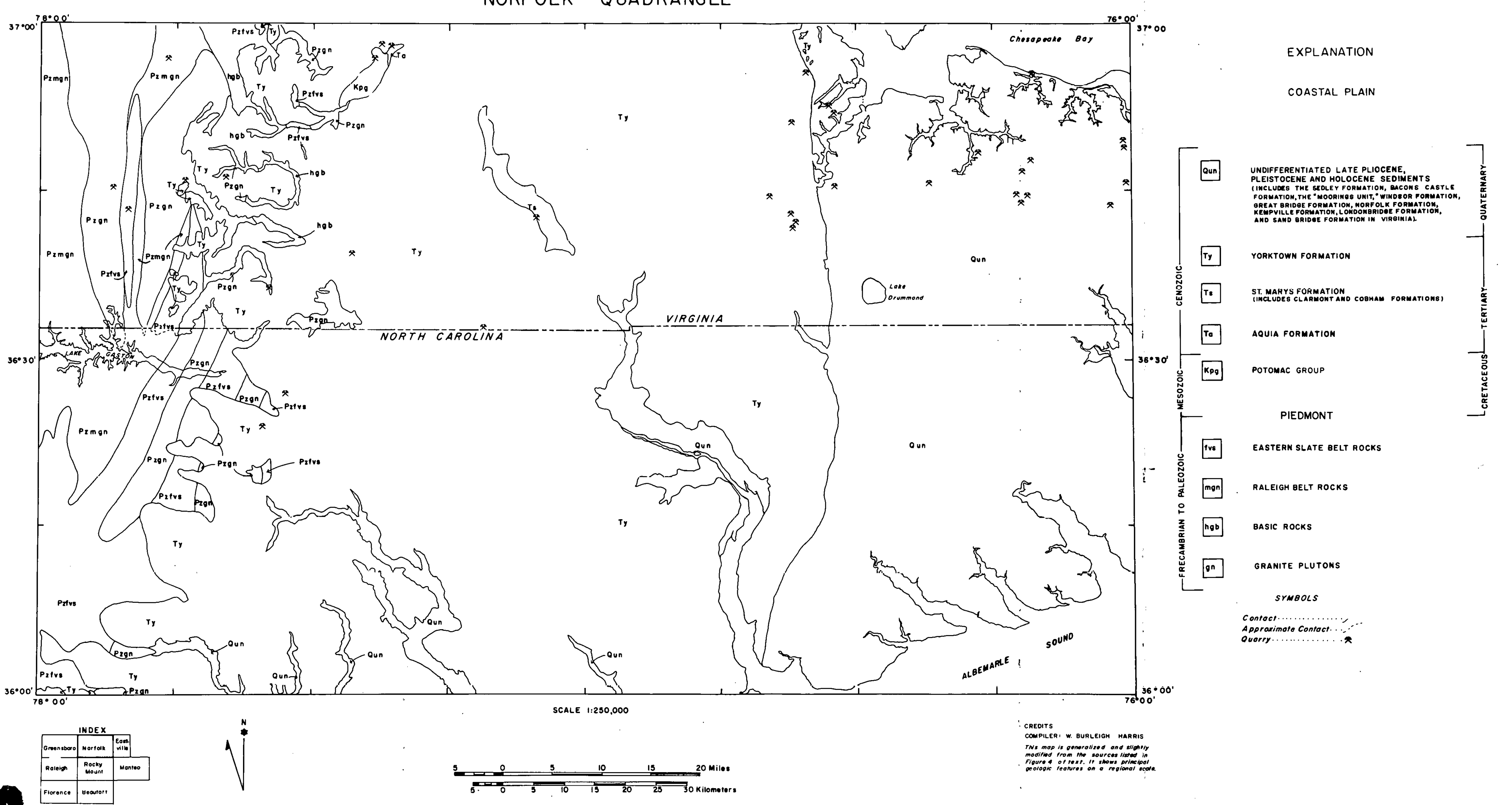

